\title{
CAROLINE HICKMAN
}

\section{“ANY EVIDENCE” IN THE FAMILY COURT}

\section{LLM DISSERTATION}

LAWS 592

FACULTY OF LAW 


\section{Abstract}

This dissertation examines the origins and justification for the "any evidence" rule which has been a feature of New Zealand family law for many years. The rule provides judicial discretion to admit evidence in the Family Court which would be otherwise inadmissible. Its ongoing value has never been closely examined, although the rule has frequently been criticised.

Selected cases have been examined to determine if reliance on the Evidence Act without the "any evidence" rule would have the deleterious outcomes contemplated. Analysis has shown that the rule has very little use and conversely, that the detriment caused by the rule is greater than the harm it was designed to remedy.

Repeal and reform options are considered to better achieve the specific purposes of the various family law statutes as well as improve the integrity of the Family Court process overall.

\section{Acknowledgments}

I gratefully acknowledge the contribution of my supervisors. Along with his wisdom, Professor Bill Atkin provided unerring support and encouragement throughout the duration of this dissertation. Before she took up post as Professor at Canterbury University in 2017, Elisabeth McDonald challenged and inspired with her invaluable insights as co-supervisor.

\section{Word length}

The text of this paper (including abstract, table of contents, footnotes and bibliography) comprises approximately 35039 words. 


\section{TABLE OF CONTENTS}

CHAPTER I Introduction of the "any evidence" rule ..................................................................5

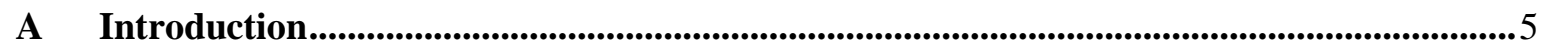

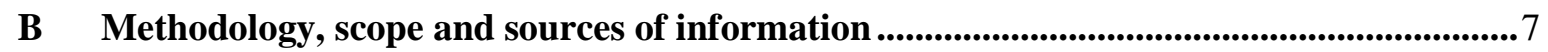

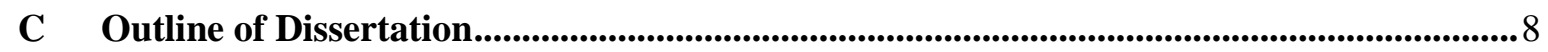

CHAPTER II Theoretical basis for the "any evidence" rule .....................................................10

A The Family Court as inquisitorial and other courts operating with a similar rule .......... 10

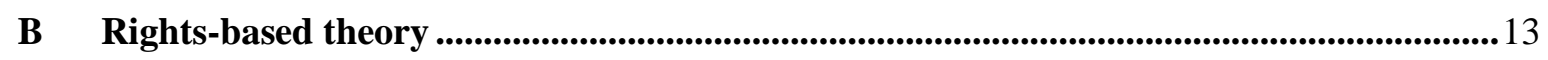

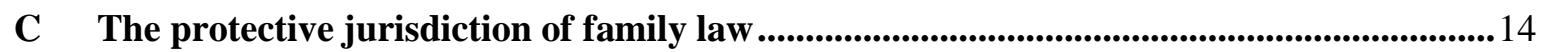

CHAPTER III Overview of evidence and specific issues in the Family Court .......................... 16

A The new "any evidence" rule ........................................................................................................... 16

B Purposes and objects of Family Court rules................................................................. 18

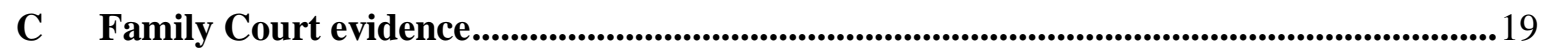

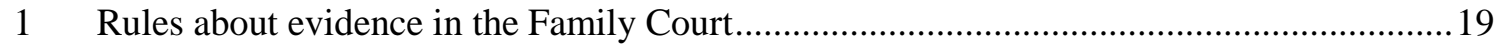

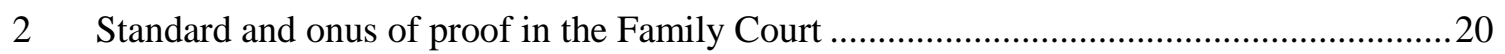

3 Admission under the "any evidence" rule as an exercise of judicial discretion ...................21

4 The impact of without notice applications on Family Court evidence ..................................22

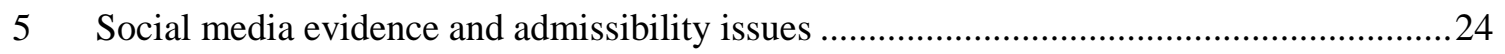

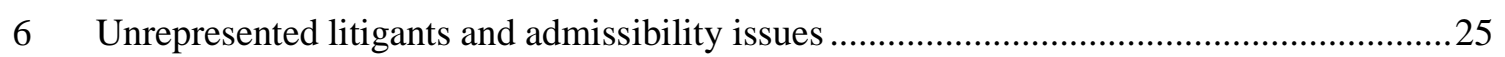

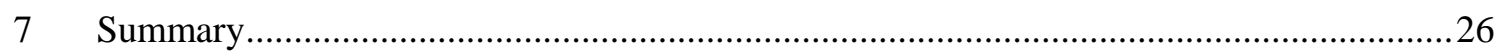

CHAPTER IV The "any evidence" rule - pre-Evidence Act 2006..................................................27

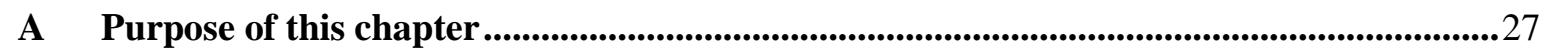

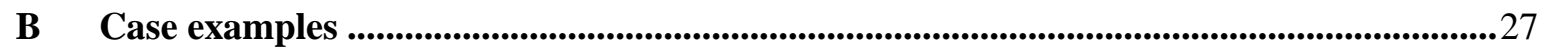

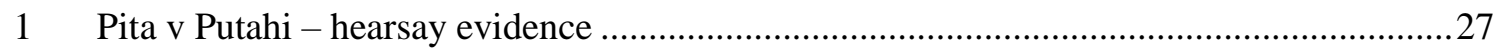

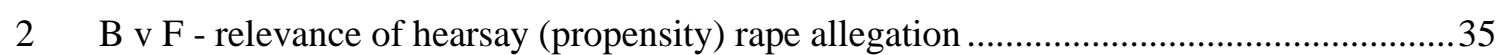

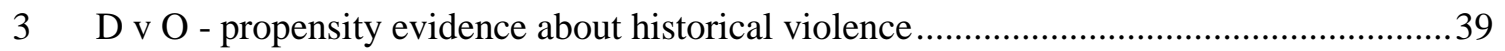

4 Taylor-Edwards v Palmer - prior court proceedings as propensity evidence ........................40

$5 \quad \mathrm{~T} v \mathrm{G}-\mathrm{unlawful}$ or irrelevant - use of transcripts of taped conversations.............................42

6 Banda v Hart - propensity evidence about behaviour of spouse .............................................4

C Was the "any evidence" rule necessary in those cases? .......................................................45

CHAPTER V The application of the Evidence Act 2006 and the "any evidence" rule ..............47

A The impact of the Evidence Act 2006 in the Family Court .....................................................47

B Is admissibility more limited under the new "any evidence" rule? ....................................53

C Conclusion - is the "any evidence" rule still needed after the Evidence Act 2006?..........62

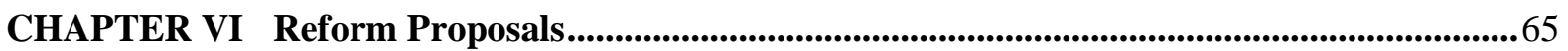

A Comparative Jurisdictions - England (and Wales) and Australia .......................................65

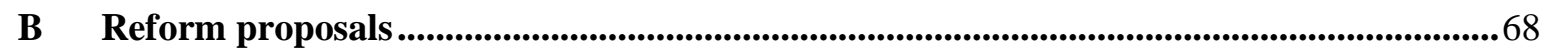

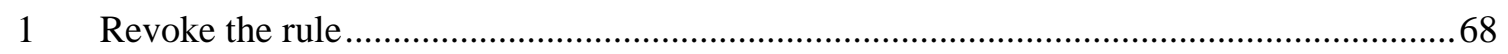

2 Revoke the rule and amend the Evidence Act 2006 definition of availability .....................69

3 Limit the rule to cases involving children or children's hearsay evidence only...................70

(a) Limit the rule so that the test is the child's best interests and welfare ................................ 70

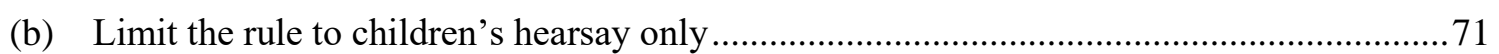


4 Other procedural reforms which may assist

(a) Require hearsay to be remedied after a without notice application if objection raised ........72

(b) Amend the rule to limit the scope of the discretion and allow lawyers to act .......................73

(c) Greater judicial case management and use of interlocutory procedures ............................... 74

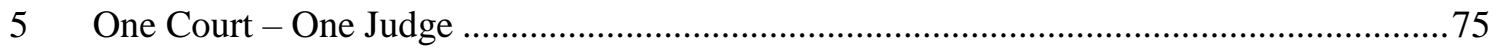

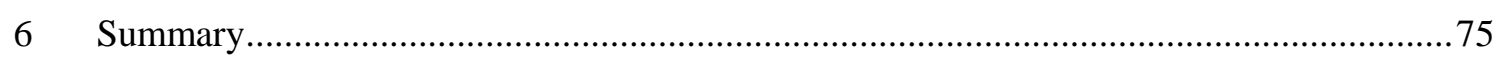

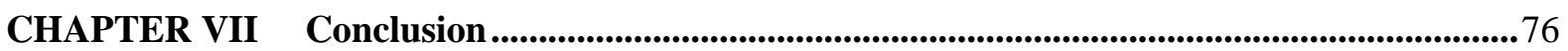

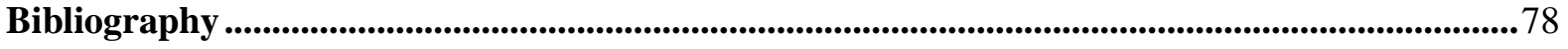

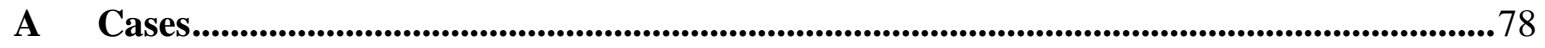

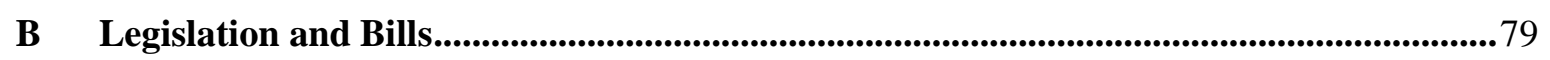

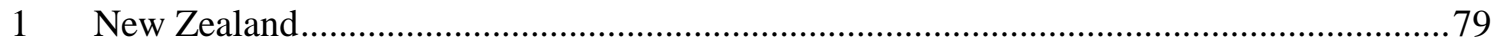

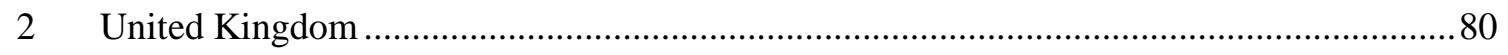

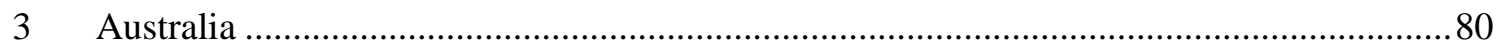

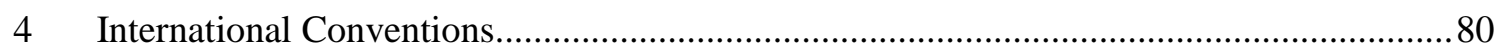

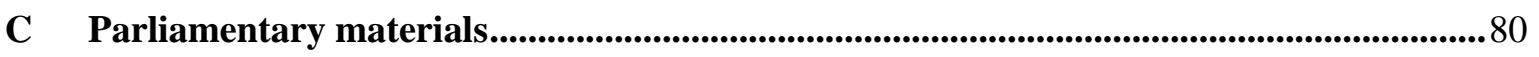

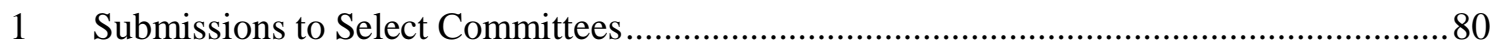

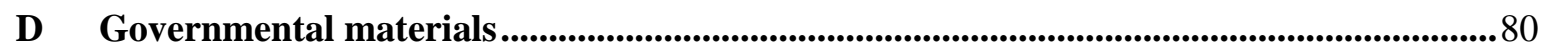

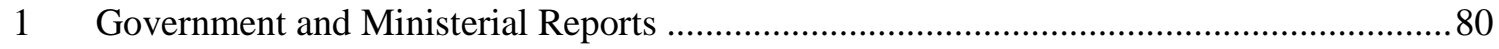

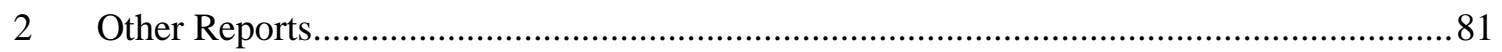

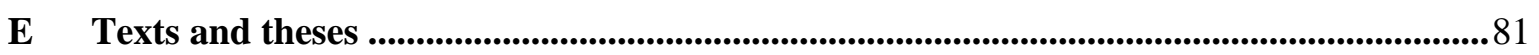

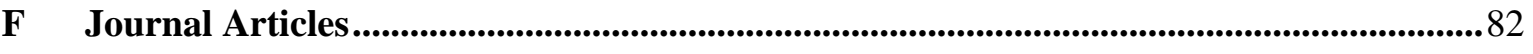

G Looseleaf Texts and online materials .................................................................................. 82 
CHAPTER I Introduction of the "any evidence" rule

\section{A Introduction}

Family law statutes have for many years contained an evidential rule ${ }^{1}$ which allows the court to admit any evidence that it thinks fit, whether or not it would otherwise be admissible. This rule is peculiar to the Family Court, although it appears in similar form in other statutes. ${ }^{2}$

Historically, the Destitute Persons Act $1910^{3}$ included a version of the "any evidence" rule which was subsequently adopted by the Domestic Proceedings Act 1968, ${ }^{4}$ the Family Proceedings Act $1980^{5}$ and then by other family law statutes. The rule is often justified on the basis that special rules are needed in cases dealing with decisions about children and other vulnerable citizens and about intangible concepts such as emotions. ${ }^{6}$

Since the rule first came into existence, its necessity has apparently never been questioned although it has frequently been criticised and labelled the "all evidence rule." The ability to depart from strict evidential rules in the Family Court has led to sloppy pleadings and affidavits which are long and discursive, having a tendency to "...mushroom, with irrelevance piled upon irrelevance, accusation upon accusation, and with the parties becoming increasingly and unproductively inflamed...". Affidavits often contain material which is hearsay, non-expert opinion, ${ }^{9}$ argument, repetition, inflammatory or self-serving comment and privileged or confidential information. Liberties have been taken with the rule to the extent where one judge commented that: "Relaxation of the rules of evidence is not a licence for evidential anarchy." 10

The theory behind the rule is two-fold: the first is that better outcomes can be reached if all important information is available to the court with nothing inadvertently omitted; the second

“...somewhat pejoratively called 'the any evidence' rule..." as noted in David Beattie Royal Commission on the Courts (Wellington, NZ Government, 1978) at [43] ("The Beattie Report").

Alcoholism and Drug Addiction Act 1966, s 30; Resource Management Act 1991, s 276; Coroners Act 2006, s 79; Te Ture Whenua Maori Act 1993, s 69; Mental Health (Compulsory Assessment and Treatment) Act 1992, s 22; Intellectual Disability (Compulsory Care and Rehabilitation) Act 2003, s 127. Section 68.

Section 114.

Section 164.

For example, a reasonable subjective fear of future violence: Surrey v Surrey [2010] 2 NZLR 581, [2010] NZFLR 1 at [77].

Stephen van Bohemen "Evidence: When it's an issue in the Family Court" (LexisNexis Child and Youth Law Conference, Auckland, 2009).

Per McGechan J in Donovan v Graham (1991) 4 PRNZ 311. And for research about the effects of inaccurate, untruthful or inflammatory affidavits on Family Court participants see Nicola Taylor "Care of Children: Families, Dispute Resolution and the Family Court” (PhD Thesis, Otago University, 2005) at 283.

Although s 24 of the Evidence Act 2006 permits opinion evidence if "that opinion is necessary to enable the witness to communicate, or the fact-finder to understand, what the witness saw, heard, or otherwise perceived."

Per Judge Murfitt in $D v O$ [2006] NZFLR 137, (2005) 24 FRNZ 894 at [22]. 
is that proceedings will be disposed of more efficiently if the steps necessary to resolve admissibility questions are bypassed.

Evidence law has been described as having the purpose of "apportionment of risk in adjudicative fact-finding". ${ }^{11}$ The same purpose underlying the "any evidence" rule also drives the regulation of judicial fact-finding; namely the balance between the need for complete information and the time/cost efficiency in assembling all the relevant information. This balance has been described as the allocation of the risk of error between parties with the tradeoff between the substantive cost of errors and the cost of fact-finding procedures that are aimed at avoiding those errors. ${ }^{12}$ The doctrine of free proof (or free evaluation of evidence) advocates that fact-finders do not need legal rules in order to determine facts. ${ }^{13}$ The doctrine underpins the "any evidence" rule in the Family Court by promoting the idea that "more information arguably produces greater accuracy". ${ }^{14}$ The proliferation of digital information now available (and produced in the Family Court) irresistibly promotes this idea. While instinctively appealing as a premise, supplementing incomplete information with information of "uncertain credentials" increases the risk of fact-finding error due to the new information's credibility. ${ }^{15}$

When commenting on the purpose of the rule, Inglis referred to the risk inherent in the rule as follows: ${ }^{16}$

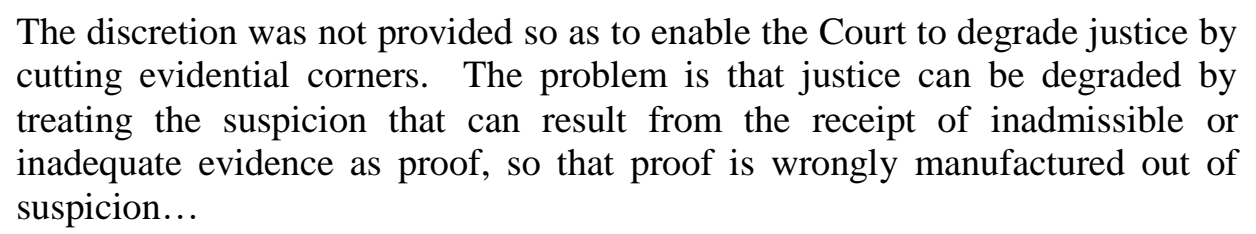

The problems associated with inadmissible evidence are axiomatic. Improper evidence can result in proceedings being protracted and becoming side-tracked by irrelevant information which inadvertently becomes a central focus. A recent case commenting on the criticism of the Family Court permitting too much evidence which does not meet acceptable standards of relevance and objectivity in the Evidence Act 2006 is that "the other party will feel obliged to address it." 17

Cases often take months or years to resolve despite the statutory principle that children's cases should be decided and implemented within a timeframe appropriate to a child's sense of time, ${ }^{18}$

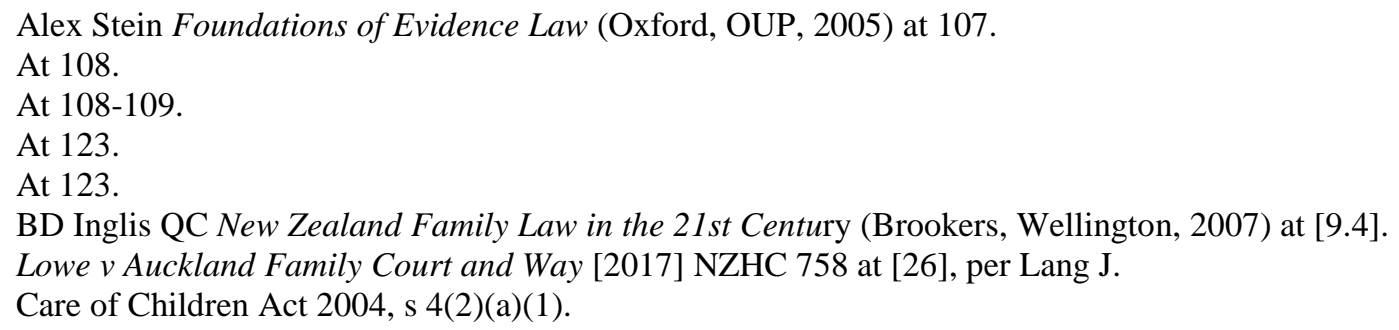


and there are rare cases which outlast a child's childhood. ${ }^{19}$ Relying on or including inadmissible evidence runs the risk of creating unfairness to participants in both process and outcome.

This dissertation examines whether the underlying theoretical justification for the rule supports its continuation in the face of the detriment created by the rule. This research suggests that revocation or radical reform of the rule would result in speedier and more effective court processes, as well as better outcomes for participants. Any perceived lacunae arising in the absence of the rule should be overcome by the Evidence Act 2006 which provides greater scope for admissibility of essential evidence than was previously available.

The "any evidence" rule also contains a facet of judicial discretion, itself a concept inherently at odds with fact-finding rules designed to decrease the risk of error. A more principled approach to the admission of evidence, rather than one based on judicial discretion, would have the additional benefit of increasing public confidence in the Family Court. These outcomes would better meet the two-fold purposes identified in the "any evidence" rule itself.

\section{B Methodology, scope and sources of information}

To provide some context, historical legislation was examined to determine how the "any evidence" rule became part of the evidential landscape of the Family Court. Academic commentary on the "any evidence" rule, covered in Westlaw NZ and LexisNexis, provided background and preliminary information. Relevant journal articles dealing with the treatment of evidence in family law were located using online databases, although there is limited academic discussion about this area generally. Text books were consulted to provide a greater understanding of the theoretical framework underlying family and evidence law.

The Ministry of Justice provided some helpful information in response to an Official Information Request regarding the proposed amendments to the "any evidence" rule resulting in s $12 \mathrm{~A}$ of the Family Courts Act 1980 . In addition, publicly available documents ${ }^{20}$ also provided valuable insights. Citations of all material referred to can be found in the bibliography.

The method of research for this dissertation has involved reading a wide range of family law admissibility decisions. Certain cases decided before and after the Evidence Act came into

\footnotetext{
19 Under the Care of Children Act 2004 parenting orders cease to apply to children over 16 (except in special circumstances) although parents retain theoretical control as guardians up until the child is aged 18.

20 Ministry of Justice Reviewing the Family Court: A public consultation paper (20 September 2011) and Ministry of Justice Family Court Proceedings Reform Bill Departmental Report (April 2013).
} 
force were chosen for analysis under the Evidence Act 2006 to determine whether critical evidence would be excluded without the "any evidence" rule to rely on.

This dissertation is limited to the narrower issue of admissibility under the "any evidence" rule rather than a more comprehensive discussion about different categories of evidence, or further evidence on appeal. While there is a wealth of jurisprudence discussing the "any evidence" rule in confidentiality cases such as Pallin, ${ }^{21}$ confidentiality ${ }^{22}$ and privilege ${ }^{23}$ are essentially concerned with non-disclosure rather than admissibility. Different policy considerations apply to whether a party can compel disclosure compared with whether evidence is admissible.

Some limited research has been undertaken into the general approach to evidence in family proceedings in the comparative jurisdictions of both Australia and England (including Wales).

\section{Outline of Dissertation}

This chapter sets out the basic thesis of this dissertation that the rule, while intended to protect vulnerable persons, does not fulfil this purpose. Instead, it causes more detriment than it remedies so that repeal or reform to limit the rule's scope and application is needed. ${ }^{24}$

Chapter II sets out the theoretical framework of the Family Court and its unique jurisdiction and considers possible bases for the "any evidence" rule. It concludes that that doctrine of parens patriae underlies the justification for the "any evidence" rule.

In Chapter III, specific issues of evidence in the Family Court are highlighted with an overview of the operation of the "any evidence" rule and the specific purposes and processes of the Family Court relevant to the rule.

Chapter IV examines selected admissibility cases and the use of the "any evidence" rule before the Evidence Act 2006 came into force.

Chapter V examines the approach taken by the Family Court in cases decided after the Evidence Act 2006 and after the new "any evidence" rule came into force. ${ }^{25}$ It discusses

Pallin v Dept of Social Welfare [1983] NZLR 266, (1983) 2 NZFLR 321, (1983) 1 FRNZ 117 (also known as $P v$ Dept of Social Welfare) a child protection case dealing with confidential information from medical professionals about alleged abuse where a mother was suspected of suffering from factitious disorder by proxy. 
whether the Evidence Act and the subsequent "any evidence" amendment have impacted on the use of the "any evidence" rule to determine if the rule is still necessary and fit for purpose.

In Chapter VI proposals for reform are considered which may provide a more disciplined approach to admissibility, creating more efficient processes and better outcomes for participants in the family justice system.

Chapter VII summarises the conclusions reached after the case analyses and discusses possible reform options. 
Consideration of possible theoretical bases for the "any evidence" rule may explain why the rule was originally regarded as necessary and provide insights about its continued justification. Possible theories supporting the rule are the concept of the Family Court as inquisitorial compared with other "investigative" courts and the current rights-based discourse. Lastly, the ancient parens patriae doctrine and the State's role in protecting vulnerable persons is proposed as the most likely theoretical basis for the rule.

\section{A The Family Court as inquisitorial and other courts operating with a similar rule}

The Family Courts Act $1980^{26}$ created Family Courts with the intention of departing from the strict adversarial model following a suggestion in the Beattie Report. ${ }^{27}$ The less-adversarial approach ${ }^{28}$ is achieved by reducing formality and unnecessary technicality; ${ }^{29}$ requiring lawyers (as far as possible) to act in a way that promotes conciliation ${ }^{30}$ and relaxing the rules of evidence. There is less emphasis on onus and burden of proof, particularly in relation to children, although each party still bears the burden of proving particular elements of their claim. ${ }^{31}$ The Family Court is also provided with other powers, such as the power to call "any person whose evidence may in its opinion be of assistance to the court", ${ }^{32}$ and the Court's power "to do what is necessary, on a case by case basis, to enable the Court to exercise its statutory functions, powers and duties is well established." 33 Family Court proceedings have been described by the High Court as "inquisitorial with no rigid exclusions for inadmissibility". ${ }^{34}$ It is this feature of the Family Court which is often used to justify the "any evidence" rule and a lenient approach to the admission of evidence.

The District Court has concurrent jurisdiction in respect of some matters although in practice it would be unusual for it to exercise that jurisdiction. The Family Court can transfer matters for determination to the High Court in respect of relationship property. The Beattie Report, above $\mathrm{n}$.

The current family law movement of "Collaborative Law" is an extension of the concept that lawyers working together in a non-adversarial way will better further the interests of their respective clients than those adopting positions of warring factions. It involves lawyers and clients having a series of meetings with relevant professionals where the option of court resolution is removed and the dispute is mutually problem solved in a positive and open way. For more information see: 〈www.collaborativelaw.org.nz〉. Family Courts Act 1980, s 10.

Family Courts Act 1980, s 9A.

For example, the existence of a de facto relationship: TJD $v$ TLB FC Napier FAM-2005-041-591, 13 July 2007.

Family Proceedings Act 1980, s 165(1).

Simon Jefferson QC “A Review of the Family Court 2011: Sorry, Snow White Can't Afford Dwarves This Year" (paper presented to Parliament in 2011 at the Symposium on Family Law, Wellington, 2011) at 49 citing McMenamin v Attorney-General [1985] 2 NZLR 274. The Family Court Rules 2002, rr 1216 also provide this jurisdiction.

BSH v Ministry of Social Development HC Wellington CIV-2009-485-000403, 13 August 2009. 
The fact that the court has been permitted to operate in an "inquisitorial" way in appropriate cases has never been questioned. ${ }^{35}$ Referring to these powers, judges sometimes declare that they are "exercising the court's inquisitorial function." 36

However, the Family Court does not operate as a truly inquisitorial or investigative court so as to justify consideration of evidence which does not meet accepted standards. It cannot call for inquiries and has limited powers about directing the provision of information. Counsel present the case through the evidence adduced and the Judge cannot direct the inquiry by questioning witnesses unrestrainedly. The Family Court has been criticised for entering into the arena of cross-examination and treating the case as the court's own inquiry. ${ }^{37}$ A truly inquisitorial court operates by the court directing investigations with the assistance of counsel.

Other courts which are also considered as operating in an inquisitorial way have wider investigative powers than those of the Family Court. The Environment Court, ${ }^{38}$ Māori Land Court $^{39}$ and Coroners Court ${ }^{40}$ all use variations of the "any evidence" rule for the admission of evidence, and can call for inquiries to be made and evidence to be provided. These courts share the characteristic that they are concerned with subject matter that may not be capable of precise proof and definition, such as potential future harm to the environment, speculation about possible contributors to the cause of death and land claims based on historical whakapapa not recorded in writing. The argument that the nature of information in family disputes is less amenable to proof by traditional means ${ }^{41}$ has also been raised as justification for the "any evidence" rule in the Family Court. It is useful to consider whether the same theoretical justification for the "any evidence" rule in those other courts is applicable to the Family Court.

The purpose of the Resource Management Act 1991 (the "RMA") is to promote the sustainable management of natural and physical resources. ${ }^{42}$ This is a forward looking, preventative, precautionary and proactive purpose requiring predictions about future effects on the environment and how to mitigate against potentially harmful risks. ${ }^{43}$ Such a speculative future focus has some comparison with the Family Court which often has to make predictive

$35 \quad$ Re Rudd (1994) 12 FRNZ 387.

$36 \quad$ See for examples: Dept of Social Welfare v T (1988) 4 FRNZ 477 at 480 (citing Pallin v DSW [1983] NZLR 266, above n 21); Clayton v Clayton (2015) 30 FRNZ 1, at [184]; NGJ v SS [2013] NZHC 914 at [73], where Wylie J commented that the Property (Relationships) Act 1976 "gives the Court an inquisitorial role"; $M v B$ [2006] 3 NZLR 660 (CA). Judicial questioning in the Family Court in an inquisitorial manner has at times been criticised, see for example: Wells v Family Court HC Wellington, CP no. 245/94, 7 December 1994. Resource Management Act 1991, s 276(1).

Te Ture Whenua Maori Act 1993, s 69.

Coroners Act 2006, s 79(1).

Stephen van Bohemen and Jill Moss "Domestic Violence Act Proceedings - New Rigour in Evidence and Proof" (paper presented to the Family Law Conference, Positive Vibes, Dunedin, October 2015), 401.

$42 \quad$ Resource Management Act 1991, s 5.

43 Te Waru of te Ngati Rangiwewehi v Bay of Plenty District Council [2008] NZRMA 395 at [29]. 
assessments about the future, but these predictions are invariably based on past events and behaviour. While the Family Court also deals with intangible concepts, it is required to make firm findings of fact on the balance of probabilities at a hearing.

The RMA specifically allows the Environment Court to regulate its own proceedings without procedural formality where this is consistent with fairness and efficiency. ${ }^{44}$ This provision is almost identical to that set out in the purpose section of the Family Court Rules $2002^{45}$ and similar purposes echoed in other family Acts. ${ }^{46}$ However, the Environment Court is expressly freed from the constraints of the Evidence Act 2006 and has significant latitude in relation to findings of fact. ${ }^{47}$ The Environment Court must consider matters of tikanga Māori and this cultural requirement "brings the Court to the direct interface between tikanga Māori and traditional jurisprudence". ${ }^{48}$ In relation to the admissibility of evidence, the Environment Court explained that: ${ }^{49}$

Substantial matters before the Court are matters which require the Court to engage in a careful consideration of wide reaching matters that are often of interest to the general public or to a particular community, cultural or religious group. To apply the rules of evidence rigidly would unduly constrain what is a specialist Court in receiving evidence, which may help the Court to make a decision or recommendation.

The investigative nature of the Environment Court creates powers almost as wide as a commission of enquiry. ${ }^{50}$ The Coroners Court $^{51}$ and Māori Land Court have similar investigative powers. The High Court observed of the Maori Land Court that:

In keeping with its partly inquisitorial role, the [Maori Land] Court is empowered to "cause" inquiries to be made, subject only to a natural justice obligation to inform and hear both sides. ${ }^{52}$

The "any evidence" rule which operates in these other jurisdictions is necessary in the context of those wide ranging, court directed enquiries of an investigative nature. It is the investigative nature of those jurisdictions which underpins the use of the "any evidence" rule and distinguishes those jurisdictions from the Family Court.

Resource Management Act 1991, s 269.

Rule 3.

Such as the Property (Relationships) Act 2002, s 1N(d) and the Domestic Violence Rules 1996, s 4.

Resource Management Act and commentary on s 276 (Westlaw NZ, Wellington, 2017, online looseleaf ed) at [A276.03].

$48 \quad$ Te Waru o te Ngati Rangiwewehi, above n 43 at [31].

49 At $[30]$.

50 At [24].

$51 \quad$ Under the Coroners Act 2006 s 3, the purpose of the Act is to help prevent deaths and promote justice by providing for the investigation and identification of causes of sudden or unexplained or deaths in special circumstances and to make recommendations to reduce future deaths in similar circumstances.

52 The Proprietors of Mangakino Township v Maori Land Court HC Wellington CP252/9, 5 May 1998 at 27. 


\section{B Rights-based theory}

Rights-based theory features largely in current legal discourse, and family law jurisprudence is no exception. The "any evidence" rule creates a "right" to introduce any evidence the court thinks fit and its admission is only limited by the court's own assessment of fitness. All Family Court participants are equally entitled to the rights protected under the New Zealand Bill of Rights Act 1990, such as the right to natural justice and the right to a fair trial. The right to be heard (the audi alteram partem rule) encompasses the right to question any witness by crossexamination, although this right is limited for self-represented respondents in criminal, domestic violence and Harassment Act proceedings. ${ }^{53}$ Evidence allowed under the "any evidence" rule, such as inadmissible hearsay, has the effect of breaching these natural justice rights as the ability to question the witness and test the hearsay statement has been abrogated by the rule.

Children's rights are specifically enshrined in the United Nations Convention on the Rights of the Child ("UNCROC") which was ratified by New Zealand in 1993. The preamble to UNCROC states that: "...the United Nations has proclaimed that childhood is entitled to special care and assistance." This statement affirms that it is the characteristic of vulnerability in childhood which warrants special protection.

The Care of Children Act 2004 enacts some of the UNCROC rights. ${ }^{54}$ Article 12 of UNCROC, affirms the child's right to have an opportunity to be heard in any judicial and administrative proceedings affecting the child. New Zealand has enacted this right by providing for the appointment of lawyers for children under s 7 of the Care of Children Act 2004 and s 159 of the Children, Young Persons, and Their Families Act 1989. ${ }^{55}$ However, this automatic right has been significantly diminished as lawyer for the child is now only appointed when the court has concerns for the safety or well-being of the child and considers the appointment necessary. ${ }^{56}$ The child's lawyer provides the opportunity for the child to express their views and ensures that these are communicated to the Family Court, usually by way of a report.

The "any evidence" rule fits into this rights-based discourse by extrapolating that the rule protects the Convention rights of a child to be heard by ensuring that their hearsay evidence is admissible even if it may not meet the ordinary admissibility threshold. This theoretical basis

\footnotetext{
53 Section 95 of the Evidence Act 2006 prohibits self-represented litigants from cross-examining complainants, parties who have made allegations of domestic violence and children (other than child complainants) unless the judge gives permission.

$54 \quad$ Care of Children Act 2004, ss 5 and 6.

55 The statutory role of lawyer for the child is set out in s 9B of the Family Courts Act 1980. One of the tasks for lawyer for the children is to meet with the children and ensure that their views are put before the court.

56 By s 7 of the Care of Children Act 2004 enacted as part of the family law amendments of 2013.
} 
presupposes that there is no other way children's hearsay could be admitted in the Family Court. It also does not explain why the rule can be used for other types of normally inadmissible evidence.

Evidential rules were devised to ensure reliability, fairness, transparency and predictability. They protect a citizen's right to a fair trial. Given the dichotomous rights of children and adults within the framework of rights, this rights-based analysis of the "any evidence" rule does not provide a coherent theoretical basis for the rule.

\section{The protective jurisdiction of family law}

Family law has been described as having a "uniquely personal and lasting impact" which has two distinct aspects, one which relates to the definition of family relationships and their legal consequences, and the other which relates to the protective jurisdiction in which the courts undertake an inquisitorial role. ${ }^{57}$ The protective jurisdiction derives from the parens patria $e^{58}$ doctrine in which the Sovereign had a duty to protect citizens unable to care for themselves. That jurisdiction devolved originally to the High Court as part of its inherent jurisdiction and the Family Court in its wardship jurisdiction. However, the breadth of the Family Court's powers is now strictly limited by statute.

The paramountcy principle itself appears to have gradually emerged as a statutory reflection of the doctrine of parens patriae, although previous laws relating to children were based on the father's (property) rights to children. The first legislation to recognise that the child's needs should be "the correct principle for deciding custody" was the Infant Custody Act 1873. ${ }^{59}$ The paramountcy provision then appeared in an amendment to the welfare provision in 1886 later reflected in the Guardianship of Infants Act $1925 .{ }^{60}$ When the Court (standing in for the State) acts protectively, it prioritises the welfare and best interests of the child as the most vulnerable citizen requiring protection.

If a strict adherence to rules means that important information relevant to a children's best interests is absent from the body of information when the Family Court decides what is in the best interest of the child, this would be seen as a failure by the State to protect the child and a breach of its duty as parens patriae: ${ }^{61}$

$57 \quad$ New Zealand Family Law in the 21st Century, above n 16 at 3.

58 Which translates as "father or parent of the country".

59 Internet source: <www.parliament.uk/about/living-heritage/transformingsociety/privatelives/relationships/overview/custodyrights>

60 See generally John Eekelaar Family Law and Personal Life (OUP, Oxford, 2006) at 141.

61 In, Bill Atkin "The Family Court System in New Zealand: Secret Justice and Privatisation" in Mavis Maclean, John Eekelaar and Benoit Bastard (Eds) Delivering Family Justice in the 21st Century (Hart Publishing, Oxford, 2015) 39 at 40. 
In short, cases involving child abuse and vulnerable adults are regarded as part of public law and the state, historically as parens patriae, has a responsibility to protect those at risk. This responsibility arguably carries over into partner abuse, although in the not too distant past this was seen as part of the private sphere.

The doctrine can be used to justify the extension of the rule to protect other vulnerable persons, such as victims of domestic violence. In that context, two aspects make an applicant particularly vulnerable; one is the significant psychological deficit operating on the applicant's ability to provide clear and coherent instructions; secondly, the inherently private nature of domestic violence results in an absence of corroborative witnesses. These two factors contribute to the view that, without some relaxation of the ordinary admissibility rules, the court may have insufficient evidence for an application to be granted.

The Family Court deals largely with vulnerable persons ${ }^{62}$ such as children, victims of domestic violence and persons with limited or no mental capacity. ${ }^{63}$ It is this unifying characteristic that provides some understanding of the theoretical basis underlying the "any evidence" rule applying across the different Acts administered by the court. This theoretical foundation supports the nexus between the protective doctrine and the "any evidence" rule. However, if this doctrine is the basis for a rule of evidence designed to protect the vulnerable, it is difficult to understand why the rule is equally available to non-vulnerable participants and proceedings which do not involve vulnerable participants.

A closer analysis of the rule indicates that it can inadvertently operate against the interests of children and other vulnerable Family Court participants by allowing unfocussed and irrelevant evidence to be admitted which breeds further conflict, obfuscates key issues and prolongs court proceedings. In that way, the rule operates against the very people it was designed to serve.

The rest of this dissertation will show that all parties to proceedings in the Family Court gain the advantage of the rule, to the disadvantage of all.

62 Defined in s 11D of the Family Courts Act 1980 as being persons who are the subject of proceedings under various listed statutes, including applicants for protection orders or protected persons under the Domestic Violence Act 1995.

63 Under the Mental Health (Compulsory Assessment and Treatment) Act 1992, the Intellectual Disability (Compulsory Care and Rehabilitation Act) 1993 and the Protection of Personal and Property Rights Act 1988. 


\section{A The new "any evidence" rule}

In the wide-ranging family law amendments that came into force in 2014, the Evidence Act 2006 was expressly stated as applying to Family Court proceedings although the "any evidence" rule was retained. ${ }^{64}$ In a scoping consultation paper, ${ }^{65}$ proposals to change the rule were canvassed and it was noted that "the standard of evidence [in the Family Court] is often poor and the 'any evidence' rule should be amended".

The amendment to the "any evidence" rule is said to be: ${ }^{66}$

...in response to criticism the Ministry of Justice received from judges, lawyers and family law academics about the any evidence rule... the Ministry was informed that affidavits were being filed that had little regard to the rules of evidence or without providing any justification for why the Court should make an exception to those rules. There was significant financial cost to parties to have prejudicial information removed.

The new formulation of the "any evidence" rule is now found in s 12A(4) of the Family Courts Act 1980. Section 12A provides:

(1) This section applies to a proceeding-

(a) under an Act specified in subsection (2); and

(b) in a court described in subsection (3).

(2) The Acts referred to in subsection (1)(a) are as follows:

(a) Adoption Act 1955:

(b) Care of Children Act 2004:

(c) Child Support Act 1991:

(d) Children, Young Persons, and Their Families Act 1989:

(e) Domestic Violence Act 1995:

(f) Family Proceedings Act 1980:

(g) Property (Relationships) Act 1976:

(h) Protection of Personal and Property Rights Act 1988:

(3) The courts referred to in subsection (1)(b) are as follows:

(a) a Family Court:

(b) a District Court that has concurrent jurisdiction with a Family Court:

(c) a District Court acting under section 15:

(d) a District Court hearing a proceeding under section 151 of the

Children, Young Persons, and Their Families Act 1989:

(e) any other court hearing a proceeding that is-

$64 \quad$ Family Courts Act 1980, s 12A.

65 Ministry of Justice Reviewing the Family Court: A public consultation paper (20 September 2011) at 48 [7.2].

66 Letter received by the writer from the Ministry of Justice dated 12 February 2016 regarding relevant information around the reform of the "any evidence" rule (Obtained under Official Information Act 1982 Request to the Ministry of Justice February 2016. 
(i) under an Act specified in subsection (2); and

(ii) not a criminal proceeding; and

(iii) one in which the court receives evidence or further evidence.

(4) The effect of section 5(3) of the Evidence Act 2006 is that that Act applies to the proceeding. However, the court hearing the proceeding may receive any evidence, whether or not admissible under the Evidence Act 2006, that the court considers may assist it to determine the proceeding.

This section asserts the primacy of the Evidence Act 2006 while retaining the "any evidence" rule. The amending Act $^{67}$ removed the "any evidence" rule from the various statutes in which it appeared and made s 12A universally applicable across the listed statutes. However, the Mental Health (Compulsory Assessment and Treatment) Act 1992 and the Intellectual Disability (Compulsory Care and Rehabilitation Act) 2003 are noticeably excluded from this list and retain their stand-alone "any evidence" provisions. ${ }^{68}$ Both deal with persons subject to mental incapacity and the hearings (at least for mental health) are informal and usually not held in the Family Court. However, the Protection of Personal and Property Rights Act 1988 also deals with incapacitated persons, yet this Act is included in the s 12A list. It is unclear whether these omissions were an oversight or whether there is some other defining trait which justifies different rules of evidence for these proceedings. The effect of the omission means that although the Evidence Act 2006 applies to these proceedings, a less arguable case can be made for its supremacy over the individual "any evidence" provisions which operate to override the Evidence Act 2006. ${ }^{69}$

In clause 62 of the Bill, ${ }^{70}$ the precursor of the "any evidence" rule was initially drafted with even wider scope so that it captured not just evidence, but "any material, whether or not admissible under the Evidence Act 2006, that the court considers may assist it to determine the proceeding" [italics added]. The term "material" was changed to "evidence" following a submission from the New Zealand Law Society as the word "material" did not clearly convey the extent to which the court could accept evidence that did not meet the Evidence Act 2006 requirements. ${ }^{71}$

When the new section was added, there were few submissions on the proposed change to the "any evidence" rule itself, possibly because the bulk of the reforms created such a radical

Family Courts Amendment Act 2013, s 9 added the repeal section as a new s 17A of the Family Courts Act 1980.

Mental Health (Compulsory Assessment and Treatment) Act 1992, s 22 and the Intellectual Disability (Compulsory Care and Rehabilitation Act) 2003, s 127. The Family Protection Act 1955 is also excluded from the list and retains the "any evidence" discretion in s 11 dealing with evidence of the deceased's reasons for dispositions.

$69 \quad$ Evidence Act 2006, s 5(1).

70 Family Court Proceedings Reform Bill 2012.

71 Submission of the New Zealand Law Society on the Family Court Proceedings Reform Bill (13 February 2013) at 57-58. 
overhaul of family law that the "any evidence" rule appeared a trivial detail by comparison. ${ }^{72}$ However the rule had already been identified as problematic, either in form or in application, in the consultation paper preceding the Family Court Proceedings Reform Bill. ${ }^{73}$

The amended "any evidence" section was considered in the Departmental report of the Ministry of Justice which concluded that: "It is important to retain this rule so that the Court has any evidence relevant to a child's welfare and best interests needed to make a decision." 74 There was no analysis about whether the Evidence Act 2006 is sufficient on its own to admit all evidence relevant to a child's welfare and best interests.

While justification for the rule was explained and considered, the Ministry of Justice did not focus on the detriment that the rule can cause. The Ministry hoped that the tick box questionnaire promulgated in the legislation as the only means to commence a Care of Children Act 2004 application would sufficiently ensure that affidavits were focused and did not contain irrelevant information. ${ }^{75}$ While the forms do force parties to address the grounds required for the court to make an order, they do not prevent hearsay, opinion and unnecessary material being introduced. Furthermore, the forms are of even less assistance than an old form affidavit as they do not help to provide a coherent narrative within which to properly understand information in context.

\section{B Purposes and objects of Family Court rules}

The Family Court Rules 2002 have the specific object of dealing with proceedings as fairly, inexpensively, simply and speedily as is consistent with justice; in such a way as to avoid unnecessary formality; and in harmony with the purpose and spirit of the family law Acts under which the proceedings arise. ${ }^{76}$ The Evidence Act 2006 has similar objectives of promoting fairness and avoiding unjustifiable expense and delay. ${ }^{77}$

72 The risk of repealing s 128 of the Care of Children Act 2004 (the "any evidence" rule in that Act) was that it: "May be detrimental to children's interests" Ministry of Justice Improving the quality of initial processes and evidence (Obtained under an Official Information Act 1982 Request to the Ministry of Justice February 2016).

Ministry of Justice Reviewing the Family Court: A Public Consultation Paper (20 September 2011). Ministry of Justice Family Court Proceedings Reform Bill: Departmental Report (April 2013) at 79.

Reviewing the Family Court: A Public Consultation Paper, above n 73 at [185] where the questionnaire type affidavit was first proposed. The requirement to use the prescribed forms is now set out in $\mathrm{r} 62 \mathrm{~A}$ of the Family Court Rules 2002. Family Court Rules 2002, r 3. Similar purposes are echoed in other family Acts such as the Property (Relationships) Act 2002, s 1N(d) and the Domestic Violence Rules 1996, s 4. Evidence Act 2006, s 6: The purpose of this Act is to help secure the just determination of proceedings by-
(a) providing for facts to be established by the application of logical rules; and
(b) providing rules of evidence that recognise the importance of the rights affirmed by the New Zealand
Bill of Rights Act 1990; and
(c) promoting fairness to parties and witnesses; and 
The logic of dispensing with the formal requirements for evidential rules by use of the "any evidence" rule as a way of reducing formality and expediting proceedings is flawed however, as including potentially unreliable evidence may add to errors in fact finding and inflate Court hearing time. As noted by Judge Adams in a relationship property case: ${ }^{78}$

...where evidence is advanced that clearly infringes the proper ambit of evidence, it should be removed so that it does not provide a distraction or an irritation for the parties. Moreover, if evidence that is truly objectionable remains on the file, it is likely to prolong the hearing and to render the forum toxic.

\section{Family Court evidence}

\section{$1 \quad$ Rules about evidence in the Family Court}

Family Court proceedings are commenced by a single form application and affidavit. This form was created with the intention of making proceedings easier for self-represented litigants and to ensure that more carefully focussed evidence is put before the court in support of an application. ${ }^{79}$ A notice of defence or response is then filed along with an affidavit in reply. ${ }^{80}$ The affidavit evidence becomes the main evidence in the case. ${ }^{81}$ Further affidavit evidence cannot be filed without first obtaining the leave of the Family Court. ${ }^{\mathbf{2}}$ While this rule is directed at avoiding the constant barrage of affidavits and affidavits in reply which can unnecessarily add extraneous issues and further intensify proceedings, the rule now means that the first affidavits filed need to be comprehensive and complete. This is often difficult to achieve when an application is filed without notice and under considerable urgency. Applications filed without notice need to include an evidential basis for the court to justify both the making of an order on a without notice basis as well as evidence to satisfy the grounds for the order sought. ${ }^{83}$

Affidavits must be limited to any matters that would be admissible if the deponent were giving the evidence orally at hearing, and reply affidavits should be "strictly limited" to matters in reply. ${ }^{84}$ Experience demonstrates that this rule is often, if not generally, overlooked by

(d) protecting rights of confidentiality and other important public interests; and

(e) avoiding unjustifiable expense and delay; and

(f) enhancing access to the law of evidence.

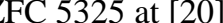

Family Court Rules 2002, rr 20 and 48. Unfortunately, while the forms may seem easier for self-litigants, they have not had the desired effect of ensuring that only relevant and focussed evidence is put before the court.

Again, the tick box form of affidavit and questionnaire combined.

Family Court Rules 2002, r 48.

Family Court Rules 2002, r 416Q.

$D v O$ (2005) 24 FRNZ 894, [2006] NZFLR 137 at 142.

Family Court Rules 2002, r 158. 
practitioners and unrepresented litigants. The Court has the power to refuse to read an affidavit if it "unnecessarily sets forth any argumentative matter or copies of, or extracts from documents" or being an affidavit in reply, introduces new matter. ${ }^{85}$ Lawyers can seek to strike out an affidavit or certain offending paragraphs if they are considered inadmissible. ${ }^{86}$

As well as the need to exclude irrelevant, inflammatory or inadmissible evidence, a lawyer also has a concomitant obligation to ensure that all relevant evidence is before the Court. Omitting relevant evidence that has a bearing on a case may equate to deception by omission. In without notice applications, there is an even higher obligation to ensure that all relevant evidence is before the court whether or not it is advantageous or detrimental to the client. ${ }^{87}$ The Family Court Rules 2002 provide for procedures to obtain additional information and this discovery procedure is more commonly used in property proceedings. ${ }^{88}$ However, interlocutory applications are costly, uncertain, and cause delay. Under the present operation of the Family Court, even obtaining hearing time for an interlocutory application could delay a substantive hearing by some months.

The issue of unfocussed and inadmissible evidence has pervaded the Family Court since its inception. Priestley J's criticism of Family Court affidavits has been frequently cited: ${ }^{89}$

A notable feature of many Family Court files is the sheer length and prolixity of filed affidavits. An affidavit is a mechanism to place relevant factual matters before the Court. It is not a device to score points, denigrate, or indulge in advocacy.

[12] ...there is an understandable temptation on the part of the parties to paint a full and self-justifying picture. Sometimes such an exercise may be therapeutic. Affidavit evidence, however, is not therapy.

[13] Solicitors preparing, and counsel settling affidavits in the Family Court ...have a professional obligation, regardless of what their "instructions" may be, to ensure that affidavits remain focused. Relevance is the first filter... ${ }^{90}$

\section{Standard and onus of proof in the Family Court}

Family Court proceedings are civil proceedings and as such the standard of proof is the ordinary civil standard of proof "on the balance of probabilities". It is often said that the standard of

\footnotetext{
$85 \quad$ Family Court Rules 2002, r 158.
}

86 Rule 170 of the Family Court Rules 2002 allows the Court to determine questions of admissibility of evidence proposed to be tendered at the hearing by a party at any stage in the proceedings. Rule 13.1 of the Lawyers and Conveyancers Act Lawyers (Conduct and Client Care) Rules 2008 provides that: "A lawyer has an absolute duty of honesty to the court and must not mislead or deceive the court." Family Court Rules 2002, rr 47, 137-155. Walker $v$ Walker [2006] NZFLR 768 at [11]- [12].

Many other types of information form evidence in the Family Court such as reports from the Ministry of Vulnerable Children Oranga Tamariki ("MVCOT"), lawyer for the child or psychologist, Family Violence Information Reports (FVIRs ) obtained from the Police and viva voce evidence at hearing. All evidence is subject to the Evidence Act 2006. 
proof is commensurate with the seriousness of the allegation so that the more serious the allegation, the greater the need for robust evidence to adequately discharge the onus: ${ }^{91}$

Rather, the civil standard is flexibly applied because it accommodates serious allegations through the natural tendency to require stronger evidence before being satisfied to the balance of probabilities standard.

The balance of probabilities test is often described as being "more likely than not" that a fact is proven. ${ }^{92}$ However, in respect of onus in family cases, the court is less concerned with who bears the burden of proof and is more concerned about whether it has enough information to be satisfied that an order is justified ${ }^{93}$ or about "a state of events which has existed, or which exists". ${ }^{44}$ The burden of proof shifts according to who has made an allegation and whether this creates is a positive duty on the other party to rebut it. ${ }^{95}$ In making out the grounds to justify an order, "both parties will carry an evidential onus in respect of matters they wish to establish". ${ }^{96}$

\section{Admission under the "any evidence" rule as an exercise of judicial discretion}

In all its various manifestations, the "any evidence" rule is drafted as providing a discretion to a hearing Judge who "may receive" or "may accept" any other evidence that would normally be inadmissible. This discretion is perpetuated by the permissive language of the "any evidence" rule reappearing in the reformulation of the rule set out in the Family Courts Act $1980 .{ }^{97}$

There are wide-ranging implications for admissibility decisions being regarded as discretionary, as decisions about evidence can alter the substantive outcome. ${ }^{98}$ A further implication of this classification relates to the more stringent appeal rights arising from an

Z v Dental Complaints Assessment Committee [2008] NZSC 55, [2009] 1 NZLR 1 at [102]. And see $T$ $v M$ (1984) 1 FRNZ 326, 328 (“...the more serious the issue the greater should be the care used in assessing it"). And see $K \vee G$ [2009] NZFLR 253 at [25] where Priestley J discussed $Z v$ Dental Complaints Assessment Committee and the "built-in flexibility" of the civil standard of proof which did not authorise a shifting or intermediate standard. Estate of Pinker v Pinker [2015] NZHC 660; (2015) 30 FRNZ 174, 177; Hv G (1999) 18 FRNZ 572, 575. Child Law [NT8.2.08] (online ed, Westlaw NZ). $G v L$ [2016] NZCA 571, [2017] NZFLR 31 at [29]. $M v B$ [2006] 3 NZLR 660 (CA) at [39]. The court concluded about the relationship property regime that: "Notions of onus of proof fit uncomfortably within this legislative regime."

Such as an allegation by one party that the other parent is using drugs. While the initial allegation needs to have some reasonable evidential basis to it, once accepted as a possible risk, the burden then moves to the other party to disprove the allegation usualy by providing a negative hair drug test.

$G v L$ above $\mathrm{n} 93$ at [29].

Section $12 \mathrm{~A}$.

Some case examples are: $T v G$ [2007] NZFLR 121, $D v O$ [2006] NZFLR 137; Banda v Hart 17 FRNZ 667; Nicholls v Nicholls [1996] NZFLR 311; Pallin v Dept of Social Welfare (1983) 2 NZFLR 321. 
exercise of a discretion. An appeal from an exercise of a discretion can only be brought on limited grounds such as the trial judge making an error of law or principle, taking irrelevant considerations into account or failing to take into account relevant considerations or that the decision is plainly wrong. ${ }^{99}$ The distinction between a general appeal and that from a discretion can be hard to draw: ${ }^{100}$

But the fact that the case involves factual evaluation and a value judgment does not of itself mean the decision is discretionary.

Characterising a decision about admissibility as an exercise of judicial "discretion" is also contrary to the principle that a decision about admissibility is a question of law not discretion. ${ }^{101}$ The Supreme Court in $R v$ Gwaze $e^{102}$ held that the admissibility rules in ss 7 and 8 of the Evidence Act 2006 do not confer a discretion but "prescribe standards to be observed" by judges in criminal and civil cases. ${ }^{103}$ Although other academic commentary confirms that admissibility decisions are questions of law while decisions about the weight of evidence are questions of fact, ${ }^{104}$ case law to date and the wording of the "any evidence" rule runs counter to that proposition. Allowing the "any evidence" rule to remain as a matter of judicial discretion invites disparate treatment between cases, and the risk of unfairness due to the more limited appeal rights.

\section{The impact of without notice applications on Family Court evidence}

Since the radical family law amendments of 2014, $86 \%$ of all applications are now commenced without notice, ${ }^{105}$ with Care of Children Act and Domestic Violence Act applications forming the majority of such applications. This phenomenon has an important impact on the quality of evidence filed. Without notice applications often need to be made on the day of a client's first meeting with a lawyer and are prepared under considerable pressure. Hearsay and other inadmissible evidence may be a necessary component of a without notice application. For example, an applicant for a protection order may have a subjective fear based on what they have been told by a third party ("he texted me that he was going to come and find you and waste you") as well as what they know from their own experience of previous violence from

\footnotetext{
$99 \quad$ May v May (1982) 1 NZFLR 165 (CA).

$100 \quad$ Kacem v Bashir [2011] 2 NZLR 1 at [32] and see Austin, Nichols \& Co Inc v Stichting Lodestar [2007] NZSC 103, [2008] 2 NZLR 141. 2014) at [EV7.01(2)], which discusses the findings in $R v$ Gwaze, [2010] NZSC 52, [2010] 3 NZLR 734. $R v$ Gwaze [2010] NZSC 52, [2010] 3 NZLR 734. At [49]. Family Law Service Evidence in the Family Court (online ed, Westlaw NZ) at [EF3.2]. "Principal Family Court Judge Ryan has advised that since the new family justice system commenced, $86 \%$ of all Care of Children Act proceedings commence on a without notice basis compared with less than 50\% before March 2014 (Morning Report, National Radio, 2 March 2016). Data from Judge Ryan.
} 
the other party. ${ }^{106}$ This evidence from third parties may not be able to be provided in an affidavit form on the day the client needs to make the urgent application. Likewise, an applicant for a parenting order may have a fear about the safety of their child in the care of the other parent having seen a Facebook post with photos apparently showing that parent using methamphetamine. Perhaps linked with that information may be the applicant's own knowledge of that parent's previous drug history. Without the Family Court being able to accept hearsay evidence from those third parties on a without notice basis at first instance, there is a risk that there would be insufficient evidence to make out the necessary grounds to justify an urgent order. Without the order, applicants and children will be left at risk.

While the urgent nature of without notice applications requires flexibility in evidential rules, there are currently no rules requiring pleadings to be later remedied (for example by filing an affidavit from a witness whose evidence was first offered as a hearsay statement). Such a rule would provide a relatively simple solution to this pervasive problem. As without notice applications entail inherent unfairness due to the court making orders without reference to the other party, significant prejudice can follow. For example, a parent's contact with their child may be prohibited or limited to only court approved contact. This prejudice endures until the court hears and amends or revokes the order. With protection orders, there is a statutory provision for mandatory hearing within 42 days when a defence has been filed. For parenting orders, there is no automatic "early" hearing time and the first court call is the Directions Conference. ${ }^{107}$ The next "hearing" of the matter must (wherever practical) be no more than 3 weeks after the Directions Conference, ${ }^{108}$ but usually will not occur for months. Final resolution may take more than a year. This delay causes unintentional consequences for children who are often bewildered about why they cannot see a parent for weeks, if not months, following a without notice order being made.

While these injustices are perpetuated by unacceptable Family Court delays, the injustice is further exacerbated if the without notice order was originally based on inadequate or improper evidence. In $S v$ Children, Young Persons and Their Families Service, ${ }^{109}$ the High Court dealt with two appeals lodged by grandparents who had previously cared for their grandchild for 10 months. The grandchild had been removed from their care following a court order made without notice on the basis of hearsay evidence from an "unnamed counsellor" who had alleged to Child Youth and Family Services that there had been violence towards the child in the home. MacKenzie J held that it was not appropriate for the Court to act on hearsay evidence which in

106 Some of the matters the Court may consider when determining whether to make a protection order are "(a) the perception of the applicant... of the nature and seriousness of the behaviour.... and (b) the effect of that behaviour on the applicant..." the Judge considers the matter is urgent and an earlier conference can be convened: Family Court Rules 2002, r 416U(3).

108 Family Court Rules 2002, r 416Z(5).

$109 \quad$ S v Children, Young Persons and Their Families Service (2007) 27 FRNZ 562. 
some cases was secondhand hearsay. He cited earlier comments by Judge Inglis QC holding that the "any evidence" rule did not confer an unrestrained licence to receive hearsay, inexpert opinion, argumentative inference purporting to be evidence of fact, or speculation, concluding: ${ }^{110}$

It is accepted that the Family Court tends to avoid unnecessary formality; but avoidance of unnecessary formality is not the same as a lax approach to basic legal principle, for the Family Court is a Court of law which is required to attain justice by a principled approach.

Another decision on the dangers of hearsay evidence is Kepa $v$ Hautapu, ${ }^{111}$ where the protection order was discharged at hearing as the primary evidence relied on was hearsay statements of threats made to other persons by telephone. Those other persons were not called for crossexamination and the respondent had denied making the phone calls. As the respondent was available and able to be cross-examined, Judge von Dadelszen held that it would be unfair to prefer "untested hearsay evidence" to the respondent's direct evidence. ${ }^{112}$

Balanced against the need to provide urgent relief for the safety of children and adults by the use of without notice applications is the risk of serious injustices if the evidence is not quickly remedied or there is a significant delay before substantive resolution.

The proliferation of evidence from electronic media (such as email and text messaging) as well as social media has become part of normal evidence in the Family Court. This presents a challenge due to issues around the sheer quantity of electronic evidence, relevance and the (sometimes) transitory nature of such evidence, as well as reliability and authenticity.

An Australian study showed that social media evidence has been offered in family cases for a variety of purposes. ${ }^{113}$ Social media evidence is frequently offered either as positive proof (such as of exchanges between the parties) or negative proof of bad behaviour of which the other party is accused. It can be useful in every area of family law but often comprises opinion or hearsay evidence and can be tainted by unreliability.

\footnotetext{
$110 \quad S v$ Children, Young Persons and Their Families Service, above n 109 at [17].

$111 \quad$ Kepa $v$ Hautapu (1998) 17 FRNZ 100.

112 At 106.

113 Victoria Blakeley and others "Social Media Evidence in Family Law: What is Probative Value of Different Types and What Kinds of Social Media Evidence Can be Used in Regards to Which Specific Rules of Evidence" (2015) 5(2) Family Law Review 81-101 (<www.ssrn .com/abstract=2664926>). Of the 136 cases which constituted the sample for the Australian study, 128 "involved evidence categorised as hearsay with 8 labelled as opinion" (electronic copy at 5.) There is no reason to suppose the nature of the social media evidence offered in New Zealand Family Court cases would be any different.
} 
The usual rules for admissibility should be applied to social media evidence, but in the Family Court, the "any evidence" rule continues to allow social media evidence to be included with little analysis about whether it passes the threshold for admissibility. The only filter for such evidence (if a challenge is made to its reliability) is a judge making a finding about the probative weight of the evidence. ${ }^{114}$

\section{Unrepresented litigants and admissibility issues}

Pleadings prepared by unrepresented litigants, with little or no legal help, often have a detrimental impact on the overall quality of evidence in the Family Court. This negative effect is compounded further when the other party responds to the inadmissible evidence which has remained unchallenged. The risk and incidence of irrelevant evidence being introduced is increased with unrepresented litigants.

When the Care of Children Amendment Act (No 2) 2013 was enacted, lawyers were barred from acting in on notice applications in care of children matters except at later hearings. ${ }^{115}$ In proceedings involving domestic violence, litigants in person may be prevented from crossexamining the applicant if the Judge exercises a discretion not to allow cross-examination. ${ }^{116}$ However, in practice, the court may of its own motion make a direction to appoint counsel to assist for the specific purpose of cross-examining.

In submissions made on the Family Court Proceedings Reform Bill, the Family Court Judges were concerned that self-litigants may struggle to comply with the Evidence Act and:117

Without guidance from lawyers, much of the evidence put before the Judge is likely to be irrelevant, inadmissible, inflammatory, unfocussed and lacking the information that is required. Judges will need to spend more time with parties and with their documents sorting out irrelevancies and pointing out the lack of relevant information.

\footnotetext{
114 In $L v R$ [2017] NZHC 590, [2017] NZFLR 177, the appellant challenged the making a final protection order against him with one of the grounds being that the Judge had relied on inadmissible hearsay evidence. An exchange of Facebook messages had been annexed the the respondent's affidavit but the other party to the exchange did not give evidence at the hearing. The High Court upheld the protection order which was made on the basis of a "constellation of factors said to amount to psychological domestic violence" (at [14]) rather than in explicit reliance on the hearsay evidence, which was unchallenged during the Family Court hearing.

115 Care of Children Act 2004, s 7A. Lawyers are permitted to act in without notice applications and currently remain able to act if the without notice application is declined in first instance.

116 After an application has been made under the Evidence Act 2006, s 95(2).

117 Paragraph 72 of those submissions.
} 
Equally problematic is the mirror issue of relevant evidence being omitted as the significance of important information is often overlooked by self-litigants. While possibly more difficult for unrepresented litigants to comply with, requiring stricter adherence to evidential rules would be of benefit to all parties and create greater fairness overall. The prevalence of selfrepresented litigants will increase unless the statutory bar on lawyers is repealed and legal aid is available to those qualifying participants. ${ }^{118}$ The issue of self-litigants will continue to impact adversely on the quality of evidence before the Family Court, particularly while the "any evidence" rule continues to offer regulatory freedom from the normal evidential rules defining admissibility. Abolition of the "any evidence" rule would go a considerable way to staunching the flow of objectionable evidence routinely included in affidavits filed by self-litigants.

\section{Summary}

The Family Court operates in the civil jurisdiction with its own distinctive characteristics, some of which derive from procedural rules and others which derive from the participants and special nature of family proceedings. As the "any evidence" rule was first adopted to cater for the particular attributes inherent in this jurisdiction, specific family cases will be analysed over the next two chapters to identify whether the rule has been required in the past and whether it continues to be necessary. 


\section{A Purpose of this chapter}

This chapter analyses selected pre-Evidence Act 2006 cases which relied on the "any evidence" rule for admission of evidence and then re-analyses those cases under the Act to determine if different outcomes would be reached without the rule. This analysis will confirm whether vulnerable participants are disadvantaged by the inadvertent exclusion of relevant evidence and whether the Evidence Act alone sufficiently fulfils its purposes. ${ }^{119}$

\section{B Case examples}

\section{$1 \quad$ Pita v Putahi ${ }^{120}$ - hearsay evidence}

In Pita v Putahi a paternal grandmother sought access to her granddaughter. The maternal grandparents cross-applied to have the father removed as a guardian as he had been convicted of the mother's murder and was serving a life sentence. He did not participate in the proceedings.

The senior police constable provided an affidavit about his direct involvement in the murder investigation and his knowledge of the previous domestic violence and substance abuse within the Pita family home. This evidence was relevant and unobjectionable. However, the affidavit annexed exhibits which were extracts from the police file including job sheets from other police officers involved in the murder inquiry and statements from third party witnesses. Those witnesses were not called so their statements were hearsay if they were being offered to prove the truth of their contents. ${ }^{121}$ It is unclear from the judgment what information was contained in these exhibits and it is assumed they contained statements about previous altercations at the family home or the actual assault causing the mother's death.

Judge Inglis relied on the "any evidence" rule in the Guardianship Act $1968^{122}$ to admit the affidavit in its entirety and held that this evidentiary section must be interpreted having regard to the welfare of the child as the first and paramount consideration. ${ }^{123}$ His Honour held: ${ }^{124}$

When ss 23(1) and 28 are read together it becomes clear that evidence having a relevant bearing on the welfare of a child is not to be excluded on technical

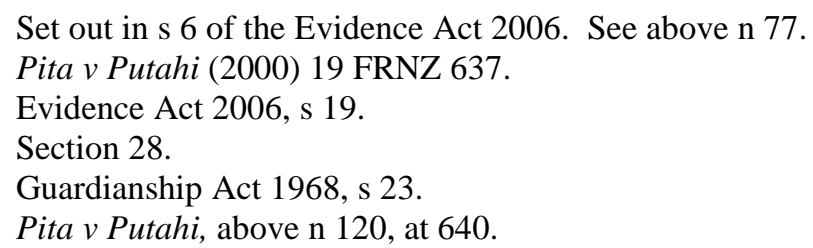


grounds alone, for the welfare of the child is the first and paramount consideration. The weight to be given such evidence is of course a different matter...

The Court did not make a pre-trial interlocutory ruling about the contested evidence but noted it would hear the senior constable's evidence de bene esse ${ }^{125}$ so that the decision about admissibility would be made after all the oral evidence had been given. This is a common approach in the Family Court which raises at least two distinct problems: one is the requirement for the other party to respond by affidavit to contested evidence in the interim. The other is that allowing evidence to be provisionally admitted creates an appearance at least that the inadmissible evidence will not be able to be "judicially disregarded" if later held inadmissible.

The concept of provisional admissibility is now preserved in s14 of the Evidence Act 2006 which allows evidence to be offered later to establish its admissibility. This section overcomes the objection made by McGechan $\mathrm{J}$ in Donovan $v$ Graham $^{126}$ about the risks of premature exclusion of the evidence "which on the more fully informed basis emerging at trial might be seen as admissible." $" 27$

In Pita, Judge Inglis had "no difficulty" in ruling the whole of the evidence admissible, although not all the evidence was entitled to equal weight. That evidence provided a "valuable, reliable and telling insight into conditions in the Pita household and into the quality of life which Rangi and her mother had while under the control of Christopher Pita". ${ }^{228}$ The evidence showed the child had been exposed to violence (including beatings which would go on for hours) and that the whole Pita household (including the paternal grandparents with whom the child and her parents resided) were "heavily" into alcohol, cannabis and violence as "an established and ingrained lifestyle." 129 The grandmother's previous cohabitation with the family and her failure to take protective action for the mother and child appeared to be fatal to her contact application.

(a) Admissibility under the Evidence Act 2006

In many cases, ss 6,7 and 8 of the Evidence Act 2006 provide a complete guide for admissibility decisions. The first step requires a consideration of relevance under $\mathrm{s} 7$. This section provides for the admission of "all relevant evidence" unless it is inadmissible or excluded under the Act or any other Act.

125 Which translates as "of well being" and indicates that the evidence will be heard provisionally or conditionally. This provisional admission is sometimes used when there is a risk that evidence will be later lost or will be unavailable.

126 Donovan v Graham (1991) 4 PRNZ 311.

$127 \quad$ At $313-314$.

$128 \quad$ Pita v Putahi, above n 120 at 640.

129 At 640. 
In Pita, the issue of whether the contested hearsay exhibits are relevant is the first step in the admissibility inquiry, as: "Relevance is an essential preliminary inquiry that can potentially affect the employment of other specific rules of admissibility set out in the Act." ${ }^{130}$ The relevance of the evidence must be measured against the two separate court applications requiring the two different issues to be decided in this case: Whether it is in the child's best interests to have her father removed as a guardian ${ }^{131}$ and whether it is in her best interests to have contact with her paternal grandmother.

Relevance is defined as the tendency of the material "to prove or disprove anything of consequence to the determination of the proceeding"132 and is set out as a two-prong test of both probativeness and materiality: ${ }^{133}$

Materiality asks whether the evidence is offered about a matter or fact at issue in the case ("of consequence to the determination of the proceeding"). Probativeness asks whether the evidence has a logical "tendency to prove or disprove" the material proposition on which it is offered. Both prongs must be satisfied to pass the s 7(3) relevance test.

While "anything that is of consequence" may initially appear to connote either probative value or even a nexus between the material presented and the ultimate issue for decision, this section has been interpreted as a 'mere relevance' threshold. There only needs to be a connection between the evidence offered and the matters requiring determination.

In $W i v R^{134}$ the Court of Appeal considered the relevance of lack of previous criminal convictions in a criminal trial. As the evidence sought to be admitted was "character evidence" at common law, it was considered as either veracity or propensity evidence under the Evidence Act 2006. The test of relevance in s 7(3) was held to be: ${ }^{135}$

...not an exacting test. Nor should it be. Any definition of relevance has to accommodate all kinds of evidence and in particular circumstantial evidence, individual pieces of which are often of slender, and sometimes very slender, weight in themselves. The question is whether the evidence has some, that is any, probative tendency, not whether it has sufficient probative tendency. Evidence either has the necessary tendency or it does not. As Lord Steyn said in $R v A$ :

[31] ... to be relevant the evidence need merely have some tendency in logic and common sense to advance the proposition in issue.

$130 \quad$ Mahoney and others, above n 101 at [EV7.04]

131 Depriving a parent of guardianship under s 29 is a serious decision and only made when the parent is unwilling to perform or exercise guardianship rights and obligations, or is for some grave reason unfit to be a guardian of the child. Additionally, the court must be satisfied that the order depriving the parent of guardianship will serve the welfare and best interests of the child.

132 Evidence Act 2006, s 7(3).

133 Mahoney and others, above n 101 at [EV7.02].

$134 \quad$ Wi $v R$ [2010] 2 NZLR 11.

135 At [8] per Tipping J. 
One way of testing relevance is to apply syllogistic reasoning to the facts proved to see if a logical conclusion can be reached from an application of a major premise to facts establishing the minor premise. The major premise in this case could be that: "Any parent who murders the other parent is unfit to be a guardian of their child". The minor premise (established by the proven facts) is that: "Christopher Pita is a parent who murdered the other parent" with the logical conclusion (inference) being reached that "Christopher Pita is not fit to be a guardian". The probative worth of the relevant evidence depends totally on the accuracy of the major premise which supports the inference. If the major premise is flawed, for not being generally accepted as an invariable premise, then the reasoning creates a false and unreliable syllogism. ${ }^{136}$ On the facts of this case, evidence about the detrimental home environment and previous domestic violence is clearly relevant to both applications before the court. There is "sufficiency" of legal relevance. ${ }^{137}$

Once the low threshold of mere relevance is reached (as the evidence only needs to have a tendency to prove something of consequence to the determination of the proceeding) ${ }^{138}$ the next step is to consider if the evidence is excluded or regulated by some other section. ${ }^{139}$ In this case the hearsay provisions must be considered.

A hearsay statement is defined ${ }^{140}$ as a statement "made by a person other than a witness" which is offered in evidence to prove the truth of its contents. Out-of-court statements made by a witness who is available to be cross examined at a hearing are not considered hearsay and are not excluded. Hearsay statements can be spoken or written assertions by a person and include non-verbal conduct that is intended by the person as an assertion of any matter.

Hearsay is only admissible if it meets the criteria for inclusion and is not otherwise inadmissible under the Act. ${ }^{141}$ It is generally admissible if the circumstances relating to the statement provide "reasonable reassurance" that the statement is reliable and either the maker of the statement is unavailable as a witness or the Judge considers that undue expense or delay would

\footnotetext{
136 Consider for example the major premise applied to the facts laid out in the novel: "The Son-in-Law" by Charity Norman (Allen \& Unwin, Sydney, 2013) where a previously devoted husband with no previous history of domestic violence delivers a single blow to the children's mother accidently killing her. Elisabeth McDonald "Evidence in the Family Court" (paper prepared for Family Court Judges, August 2011) at 5. $R v$ Smith [2007] NZCA 400 at [16]. Bernard Robertson "Bain, Bayes and basics: Relevance under the Evidence Act 2006" (2010) 24 NZULR 167 at 176 where the author sets out "the preferable approach" to the admissibility.

"The order in which questions should be asked therefore is: Is the evidence relevant, and if so to what and in what way? Is the evidence excluded or regulated by some other provision? Is the evidence excluded under s 8 ?"

140 Evidence Act 2006, s 4.

$141 \quad$ Evidence Act 2006, s 17.
} 
be caused if the maker of the statement was required as a witness. ${ }^{142}$ The inquiry is not directed at the reliability of a witness's testimony itself but at the circumstances and context in which the statement was made. The definition of circumstances in s 16 provides a non-exclusive list of factors the court can use ${ }^{143}$ including: the nature of the statement (for example whether it was "written or oral, recorded in some way, formal, signed, prepared by someone with experience, first hand etc") ${ }^{144}$; the contents of the statement (for example, whether it is an oral statement, the level of detail, whether there is lack of ambiguity, whether there is consistency throughout, and whether there is a declaration against interest or whether it is a self-serving statement); ${ }^{145}$ the circumstances relating to the making of the statement (including such things as the physical environment, the relationship between the maker of the statement and the witness, whether it was voluntary or prompted); any circumstances that relate to the veracity; ${ }^{146}$ accuracy or observation of the person (which would include such information about the state of mind or sobriety of the witness reporting the hearsay).

In Pita, Judge Inglis did not appear to distinguish between the direct evidence of the police officer and the hearsay exhibits. Up until the recent amendments to the Evidence Act $2006^{147}$ these police record job sheets and witness hearsay statements would have been admissible as business records under s 19 . The amendment was made excluding such documents as business records due to a concern that: ${ }^{148}$

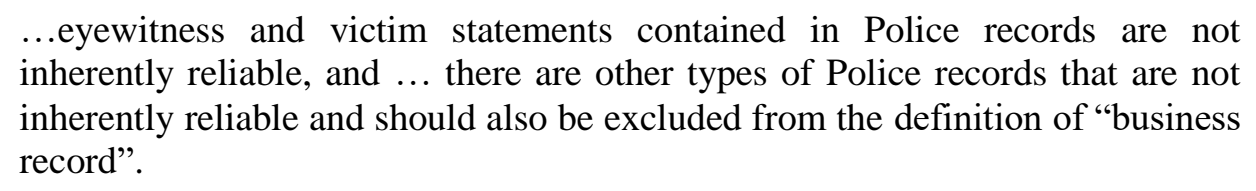

However, any hearsay that could be admitted as a business record would still needs to pass the same reliability ${ }^{149}$ and witness unavailability test ${ }^{150}$ before it can be admitted.

Admission of hearsay is also provided for in s 20 of the Act which confuses rather than clarifies admissibility of hearsay in relation to Family Court proceedings. The title of the section reads: Admissibility in civil proceedings of hearsay statements in documents related to applications,

$142 \quad$ Evidence Act 2006, s 18.

143 For a comprehensive discussion of each of the listed factors, see Mahoney and others, above n 101 at [EV16.03.01-16.03.05].

$144 \quad$ At $[\mathrm{EV} 16.03 .01]$.

$145 \quad$ At [EV16.03.01(2)].

146 This inquiry also requires that the veracity evidence meets the substantially helpful test in s 37 of the Act.

$147 \quad$ Made by the Evidence Amendment Act 2016 on 8 January 2017. The definition of business record in s 16(1) now specifically excludes “... a Police record that contains any statement or interview by or with an eyewitness, or a complainant, or any other person who purports to have knowledge or information about the circumstances of alleged offending or the issues in dispute in a civil proceeding".

148 Introduction to the Commentary in the second reading of the Bill.

149 Evidence Act 2006, s 18(1)(a).

150 Evidence Act 2006, s 19 (1)(a), (b),(c). 
discovery, or interrogatories. This appears to cover applications in Family Court proceedings. ${ }^{151}$ Section 20 of the Evidence Act 2006 side-steps the more specific provisions of ss $16-19$ relating to hearsay and reads:

(1) In a civil proceeding, a hearsay statement in an affidavit made to support or oppose an application is admissible for the purposes of that application if, and to the extent that, the applicable rules of court require or permit a statement of that kind to be made in the affidavit.

(2) In a civil proceeding, a hearsay statement in a document by which documents are discovered or interrogatories are answered is admissible in that proceeding if, and to the extent that, the applicable rules of court require or permit the making of a statement of that kind.

Prima facie, Family Court proceedings are "civil proceedings". Hearsay statements will usually be made in affidavits, and affidavits are the way proceedings are brought in the Family Court. ${ }^{152}$ Hearsay is not specifically mentioned in any of the listed family law statutes to which s 12A of the Family Courts Act 1980 applies, so that the only rule which appears to allow hearsay is $\mathrm{s} 12 \mathrm{~A}$ itself, or extant versions of the "any evidence" rule. ${ }^{153}$

Section 20(2) of the Evidence Act 2006 allows hearsay statements in documents which are "discovered", or "interrogatories which are answered" to be admitted in Family Court proceedings. ${ }^{154}$ The word "discovered" in this section suggests the formal process of discovery, something more common in ordinary civil proceedings in the High or District Court, although discovery applications can also be made under the Family Court Rules 2002. ${ }^{155}$ The conclusion must be reached that careless drafting and lack of forethought prompted the enactment of s 20 as it appears to contradict and override the careful provisions otherwise providing for the admission of hearsay.

The third step in the Evidence Act analysis is to apply the general exclusion clause. Section 8 provides a two-part disjunctive assessment about exclusion:

(1) In any proceeding, the Judge must exclude evidence if its probative value is outweighed by the risk that the evidence will-

(a) have an unfairly prejudicial effect on the proceeding; or

(b) needlessly prolong the proceeding...

The first limb of s 8 requires a balancing exercise between probative value and prejudicial effect on the proceedings. Section 8 is said to serve "the interests of accuracy, fairness and

151 This section was relied on in the Family Court to admit hearsay evidence in FSE v SJH FC Christchurch FAM-1999-009-001560/1561, 2 September 2011, probably on the basis that the "any evidence" rule was a rule of court which would permit a statement of that kind to be admitted.

$152 \quad$ Family Court Rules 2002, r 48.

153 Such as in the Mental Health (Compulsory Assessment and Treatment) Act 1992, s 22.

$154 \quad$ Evidence Act 2006, s 20(2).

155 Family Court Rules 2002, rr 140-155. 
efficiency in fact-finding". ${ }^{156}$ While it features more prominently in criminal jury trials, this may be because the fact finders (the jury) are less likely to be able to filter out and disregard unfairly prejudicial evidence and to appropriately weigh up any unfair prejudice it may bring. In the Family Court, the s 8 balancing exercise is rarely explicitly undertaken. The judiciary considers itself able to "sort out the wheat from the chaff" and sift through the material presented, so that if a piece of evidence is unfairly prejudicial to one party, it can be set aside.

The risk of not explicitly addressing s 8 is that undue weight can inadvertently be placed on evidence which may either prejudice a party or be tangential to the central issue and likely to unnecessarily prolong proceedings. This could result in an outcome which is unfair to a party, or in the case of children, not in their best interests.

Other parties or witnesses who may be unfairly prejudiced in the proceeding also need to be considered in the weighing up exercise, whether they are applicants or respondents. In Black $v R,{ }^{157}$ the Court held that the unfair prejudice exclusion needed to "take into account the interest of the prosecution as well as the defence". By analogy, the interests of both parties in a civil proceeding need to be considered in the s 8 balancing exercise, although it is the child's best interests and welfare that will always tip the balance either way. ${ }^{158}$ This is because s 5 of the Evidence Act 2006 provides that the Act is subject to "any other enactment" 159 in the event of any inconsistency, rendering the Act nugatory, unless the Evidence Act 2006 provides otherwise. ${ }^{160}$

The evaluative exercise in s 8 in determining the probative value of evidence is similar to that needed when the Judge ultimately determines the weight to be given to particular evidence, "... although decisions of weight are for the fact-finder as a matter of proof, and only rarely for the judge as a matter of admissibility". ${ }^{161}$ Promoting fairness to parties and witnesses and avoiding unjustifiable expense and delay are guiding principles ${ }^{162}$ when weighing up admissibility exclusions under s 8 .

\footnotetext{
$156 \quad R v$ Bain [2009] NZSC 16, [2010] 1 NZLR 1 at [41].

157 Black $v R$ [2012] NZCA 482 at [31]. See also Mahoney and others, above n 101 at [EV8.01(2)].

158 The child's welfare is the first and paramount consideration in administrative and substantive decisions affecting children: Care of Children Act 2004, s 4 and the Children, Young Persons, and Their Families Act 1989, s 6.

159 "Enactment" in s 5 includes the whole of an Act as well as regulations (Interpretation Act 1999, s 29). Rules of court made under any enactment with the concurrence of two or more members of the Rules Committee are subordinate to the Evidence Act 2006. However, as the Family Court Rules were not created by a "rules committee comprising 2 or more members," they are strictly rules which will prevail over the Evidence Act 2006 in cases of inconsistency: Mahoney and others, above n 101 at [EV5.02] n 194.

160 Evidence Act 2006, s 5(1).

$161 \quad$ Elisabeth McDonald Principles of Evidence in Criminal Cases (Brookers, Wellington, 2012) at 2.3.1.

162 The purpose of the Evidence Act 2006 set out in s 6(c) is to help secure the just determination of proceedings by “...(c) promoting fairness to parties and witnesses...”.
} 
The police officer's evidence about the child's home environment and what he had witnessed with domestic violence and substance abuse within the paternal family would still be available under any Evidence Act analysis. Unless his credibility was impugned in some way, the police officer's direct evidence of what he had witnessed would normally be regarded as reliable and unobjectionable without the need for corroboration. While the Evidence Act 2006 provides guidance for corroboration in the criminal context, there do not appear to be any sections relevant to the civil context. ${ }^{163}$

The overwhelming volume of prejudicial evidence offered with the addition of annexures to the police officer's evidence must have impacted on the perception of the Court and the decision to remove the father as guardian and refuse the paternal grandmother contact. While prejudicial, the evidence also has a high probative value as it relates closely to child safety and wellbeing. There can be no question that the probative value clearly outweighed its prejudicial effect under s 8 if the exhibits were viewed in isolation. If viewed as part of a body of information already before the Court however, the prejudicial affect would outweigh the probative value.

The second limb of s 8 requires a separate inquiry about whether the evidence would needlessly prolong the proceedings. If all the witnesses whose hearsay statements were annexed to the police officer's affidavit were summonsed and available, adding those witnesses would needlessly prolong the hearing, the prolongation would be needless if the witnesses were all giving similar evidence. Under the Evidence Act 2006, the Court may have elected to exclude some, or all, of the exhibits annexed to the senior police officer's affidavit as the prejudicial effect almost certainly outweighed its probative value when viewed as a whole. ${ }^{164}$ Furthermore, they may have unnecessarily added to the length of hearing and may have been excluded on those grounds.

The use of the "any evidence" rule in this case allowed admission of additional material, by way of hearsay statements (business records) that would not now automatically be admissible under the Evidence Act 2006. ${ }^{165}$ If additional evidence was required from some of the witnesses who had provided evidence in the criminal investigation, this should have been provided first hand from those witnesses.

It must be assumed that even without the hearsay exhibits, the senior constable's evidence contained sufficient information to cause serious disquiet to the court about the wellbeing of the child with the paternal family. Conclusive evidence that the father murdered the child's

\footnotetext{
$163 \quad$ Evidence Act 2006 s 121.

164 Evidence Act 2006, s 8.

165 Police records are now excluded from the definition of business records. See above n 147.
} 
mother is going to be strong evidence on its own in any child welfare inquiry. ${ }^{166}$ The hearsay exhibits would only have the effect of corroborating and enlarging upon the police officer's evidence and "gilding the lily", but were unnecessary in any final analysis. However, the judge's role as gatekeeper of evidence and his approach in this case is unlikely to trouble most of the community who would share the Judge's world view about the repugnance of such a home environment for a child. While the job sheets and additional witness statements would now be likely to be excluded as they would not be admissible as documentary hearsay, they were not necessary for the court to reach the conclusions it did. Without the "any evidence" rule, different decisions would be made about admissibility, but they would not have changed the ultimate outcome in view of the other evidence already available.

However, a different outcome may be reached, particularly about the grandmother's contact application, if the Family Court was deciding the case today. Principles about protecting and promoting ongoing relationships with parents and whānau, and for a child's sense of identity to be preserved and strengthened are spelt out in the Care of Children Act 2004. ${ }^{167}$ These principles may now sway a Family Court to make a contact order (albeit a limited and supervised one initially) in favour of the paternal grandmother, but this interesting speculation is outside the scope of this dissertation.

\section{$2 B v F$ - relevance of hearsay (propensity) rape allegation}

In $B v F^{168}$ the Family Court evaluated admissibility in a case where the father had applied for unsupervised contact (access) with his child. In the mother's affidavit, she alleged that the applicant drank too much; had sexually abused the mother's child of a different relationship and that he had raped the mother's sister. The purpose of offering this evidence was that, when added to the other risk factors, it elevated the risk of harm from unsupervised contact with the child's father. The mother's evidence of the alleged rape was hearsay evidence as it was being offered to prove that the rape had occurred and that: "it indicated that the father's sexual propensities in regard to females were not limited to any one age range and related generally to the father's unreliability in sexual matters".

\footnotetext{
166 Evidence Act 2006, s 47 . Evidence of a criminal conviction is conclusive evidence that the person committed the offence.

167 Care of Children Act 2004, s 5(e) and (f) provide that:

(e) a child should continue to have a relationship with both of his or her parents, and that a child's relationship with his or her family group, whānau, hapū, or iwi should be preserved and strengthened:

(f) a child's identity (including, without limitation, his or her culture, language, and religious denomination and practice) should be preserved and strengthened. 
In respect of the allegations that the father had sexually abused another child of the mother, the Court sought access to all the material in the hands of the Department of Social Welfare ${ }^{169}$ and the Police. Interlocutory directions were made about the provision of further evidence for the hearing including obtaining a psychologist's report.

It was argued for the father that the rape allegation was irrelevant to the issue of the father's access to his child and that the prejudicial effect of the evidence outweighed its probative value. The mother's alleged concern about safety was undermined by the fact that she had allowed the child to be in the unsupervised care of the father for three days while she had surgery even though she had been told about the alleged rape some 13 months earlier. However, Judge Inglis QC admitted the evidence of the alleged rape in reliance on the "any evidence" rule, ${ }^{170}$ noting:

\begin{abstract}
By the ordinary rules of evidence applied in criminal and civil litigation there is no way in which the evidence of the alleged rape could be treated as admissible in respect of the principal issue in the present case. However the ordinary rules of evidence do not apply in the present case: s 28 Guardianship Act 1968. In addition, in the present case the welfare of $\mathrm{A}$ is the first and paramount consideration: s 23(1).
\end{abstract}

The implicit risk to the child arising from the allegation required admission of the evidence when weighing up the paramountcy principle. The court's decision was only about admissibility (not probative value) and: ${ }^{171}$ “ $" . .$. the Family Court is perfectly well able to place the prejudicial effect of evidence of this kind in proper perspective, treating its true weight as the primary consideration."

As a psychologist's report was directed, the rape allegation and any risks to the child would be addressed by the psychologist.

(a) Admissibility under the Evidence Act 2006

Under the Evidence Act approach, the first inquiry is always about relevance and whether the evidence has the tendency to prove or disprove anything of consequence to the proceeding. Evidence of violence, including sexual violence, would normally be considered relevant to Care of Children Act proceedings, and ss 5(a) and 5A direct that a child must be protected from all forms of violence. The safety principle ${ }^{172}$ has always been regarded as trumping all other principles relevant to a child's welfare and best interests in the Care of Children Act 2004. ${ }^{173}$

\footnotetext{
169 Now the Ministry of Vulnerable Children Oranga Tamariki (MVCOT), previously Ministry of Social Development (MSD), previously Child Youth and Family (CYFS), previously Children, Young Persons, and Their Families Service (CYPS).

170 Then available as s 28 of the Guardianship Act 1968.

$171 \quad B v F$, above $\mathrm{n} 168$ at 716.

172 Section 5(a) Care of Children Act 2004.

173 Kacem v Bashir [2010] NZSC 112, [2011] 2 NZLR 1, [2010] NZFLR 884, (2010) 28 FRNZ 483.
} 
The relevance of the allegation that the father raped the mother's sister is that it is propensity evidence. Propensity evidence is called to show a similarity with previous behaviour by a person, so that the court is invited to draw an inference that the person is capable of, or likely to, repeat this or similar behaviour. Propensity evidence may be offered in criminal and in civil proceedings and is defined under s 40 of the Evidence Act 2006 as: ${ }^{174}$

...Evidence that tends to show a person's propensity to act in a particular way or to have a particular state of mind, being evidence of acts, omissions, events, or circumstances with which a person is alleged to have been involved.

As the Evidence Act 2006 does not provide any guidance for the application of the propensity rule, ${ }^{175}$ the common law still applies and relevance will be the "main determinant of admissibility". ${ }^{176}$

There is no question that a criminal conviction for sexual offending by a parent of any type is relevant to the welfare and bests interests of the children. ${ }^{177}$ However even an unproven allegation about sexual offending will almost always meet the mere threshold test of relevance under the Evidence Act 2006, with the court's inquiry concerned more with the probative value of the evidence and the weight to attribute to the unproven allegation. While the allegation may pass the relevance test, its probative value may not be high.

It may be argued that evidence about sexual violence towards another adult does not necessarily correlate with a proclivity to use sexual violence towards children. However, if violence is viewed in the more contemporary paradigm as coercive control, the relevance is obvious, as a perpetrator is more likely to use coercive control in any form against other vulnerable persons including children. ${ }^{178}$ As is frequently noted in Family Court proceedings, past behaviour is often considered the most accurate predictor of future behaviour.

\footnotetext{
174 Section 40 is subject to ss $41-44$ in criminal proceedings.

175 Compared with the detailed and specific guidance for the use of propensity in criminal proceedings found in ss 41-43. For a useful discussion of propensity evidence in the criminal (albeit domestic) context see Thornton $v$ R [2017] NZCA 256.

$176 \quad$ Mahoney and others, above n 101 at [EV40.03(1)].

177 Evidence of previous criminal convictions can be admitted as "conclusive" evidence about the commission of those offences: Evidence Act 2006, s 47. In addition, the Criminal Procedure (Transfer of Information) Regulations 2013 provides for information sharing between the District Court and relevant courts (which includes the Family Court). Regulation 7A provides for the respondent's criminal history to be provided to the Court dealing with the domestic violence proceeding. Unfortunately, reg 7A allows transfer of information from the criminal court only for Domestic Violence proceedings and not Care of Children proceedings or other proceedings concerning children. In 2017, the Family Law Section of the New Zealand Law Society has proposed an extension of this regulation to children's cases. For a discussion of coercive control see generally, Evan Stark Interpersonal Violence: Coercive Control: The Entrapment of Women in Personal Life (Cary, OUP, 2007. ProQuest elibrary). Clause 9 of the Family and Whānau Violence Bill 2017 proposes that the definition of "family violence" includes a pattern of behaviour made up of a number of abusive acts (whether physical, sexual or psychological) which are either coercive or controlling or cause the person cumulative harm.
} 
Under the Evidence Act, once relevance is established the next step is to consider any specific rules for admissibility. In addition to the evidence in $B v F$ being hearsay, it is highly inflammatory and prejudicial. An ethical duty arises for any lawyer raising a serious allegation and it is improper for a lawyer to allow a client to depose an allegation without a proper evidential basis. ${ }^{179}$

As the evidence was hearsay, the Court would need to assess whether the hearsay evidence should be admitted. It would need to examine the circumstances surrounding the making of the statement to determine if there was reasonable reassurance that the statement is reliable, ${ }^{180}$ whether the maker of the statement was unavailable as a witness, ${ }^{181}$ or whether undue expense or delay would be caused by requiring the witness to give evidence. ${ }^{182}$ Although the evidence would have much greater probative value if the victim of the alleged rape gave evidence about the rape, this would result in the Family Court hearing becoming a de facto rape trial, without the protections for the victim that a criminal court may offer. It would also lengthen the proceedings and detract from the central issue of the child's welfare and best interests.

Unfortunately, the judgment in $B v F$ does not provide any context about the circumstances surrounding the making of the statement or the availability of the witness to make a more positive determination about admissibility under the Evidence Act provisions about hearsay. ${ }^{183}$ If admissibility was in doubt, as the evidence was clearly relevant, there would always be the possibility of having it provisionally admitted, ${ }^{184}$ subject to evidence being offered later which establishes its admissibility.

Once identified as admissible hearsay, the court would need to consider whether it should be excluded under the general exclusion clause. ${ }^{185}$ The fact that the evidence was unfairly prejudicial was still unlikely to overwhelm the need for admission having regard to issue of child safety and the paramountcy principle. The Court would also need to consider whether the proceedings would be needlessly prolonged by admission of the evidence. ${ }^{186}$

\footnotetext{
179 The Lawyers and Conveyancers Act (Lawyers: Conduct and Client Care Rules) 2008 provides: Rule 13.10.2 - A lawyer cross-examining a witness must not put any proposition to a witness that is either not supported by reasonable instructions or that lacks foundation by reference to credible information in the lawyer's possession

Rule 13.10.3 - A lawyer must not put questions regarding allegations against third parties to a witness when the lawyer knows that the witness does not have the necessary information or knowledge to answer questions in respect of those allegations, or where there is no justifiable foundation for the allegations. Evidence Act 2006, s 18(1)(a).

On one of the grounds set out in s 16(2) Evidence Act 2006.

Evidence Act 2006, s 18(1)(b)(ii).

Evidence Act 2006, ss 16-18.

Evidence Act 2006, s 14

Evidence Act 2006, s 8.

Evidence Act 2006, s 8.
} 
The real issue was the probative value of the evidence. The "any evidence" rule was not necessary for admission of this evidence but was relied on "just in case" the Judge was wrong in the first analysis. This use of the rule in this way does not justify the retention of the rule. In this case, the court would have accorded the same weight to the evidence whether it was admitted under the "any evidence" rule or the Evidence Act, as the sum of the other parts of the evidence offered was equal. This evidence was but one piece of additional, but tangential evidence in the machinery of this child contact dispute.

\section{$3 \quad \mathrm{D} v \mathrm{O}$ - propensity evidence about historical violence}

In $D \vee O^{187}$ Judge Murfitt was required to determine whether a child was safe in the unsupervised care of the applicant father. ${ }^{188}$ Two affidavits had been filed by the father's former girlfriend about his previous violence to her some 14 years earlier when they were teenagers. This evidence had resulted in an additional 19 pages of evidence, 14 pages from this witness alone. The court was asked to determine admissibility.

Judge Murfitt held that the affidavits should not be read as the alleged conduct had occurred 14 years ago and had no relevance to the central issue commenting: 189

While hearsay evidence, and opinion evidence may at times be admitted under the relaxed evidential rules, the touchstone will always be relevance and reliability.

As the applicant had already accepted that he had previously been violent to the respondent and to the child, the issue was whether the applicant had "changed course, reformed or learned new paths" and the court was unlikely to be assisted by what happened in 1992. ${ }^{190}$ The Judge noted that admitting the evidence was likely to side-track the Court into an ancillary investigation about the relationship which had ended in 1992 and therefore likely to divert the focus of the parties and their counsel into that issue, rather than the inquiry focused on the arrangements that would best meet the needs of the child.

The Judge referred to admissibility decisions being made with reference to the child's welfare and best interests as the first and paramount consideration. ${ }^{191}$ Although the "any evidence" rule was referred to, it was not accepted as providing sufficient authority to admit this historic propensity evidence as it was not relevant to the main issue in those proceedings.

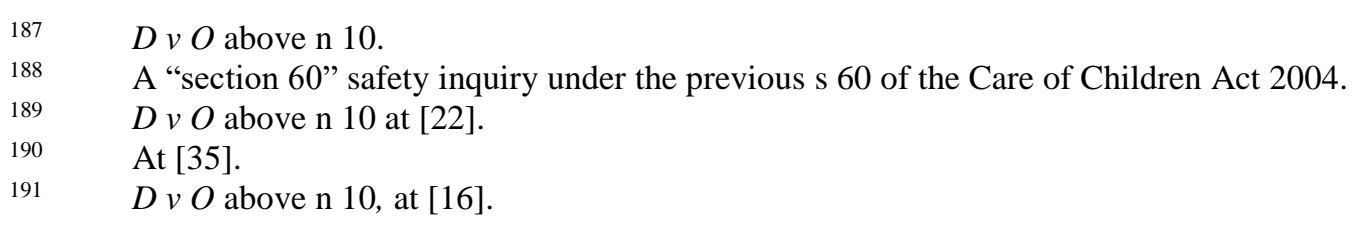


(a) Admissibility under the Evidence Act 2006

In children's cases, relevance will always be determined having regard to the welfare and best interests of the child. To determine relevance under s 7 of the Evidence Act 2006, it is essential to consider the issue at the heart of the inquiry. If the issue is whether the applicant is violent towards partners or children, then evidence tending to prove previous violence will be relevant. In $D v O$ however, the issue was whether the respondent had made the necessary changes in his behaviour so that the child would be safe in his unsupervised care. Under a relevance inquiry, the evidence from the past girlfriend was not material to a probative matter as it did not have a tendency to prove whether or not the father had made the necessary changes to reassure the court that the child was now safe in his unsupervised care. In addition, admitting the evidence would have the effect of needlessly prolonging the hearing so that even if the evidence was held to pass the threshold of mere relevance, it should be excluded under s 8 of the Evidence Act 2006. ${ }^{192}$ An Evidence Act analysis yields an identical result in this case.

\section{Taylor-Edwards v Palmer-prior court proceedings as propensity evidence}

The Family Court dealt with an application by the mother to remove the father as a guardian in Taylor-Edwards $v$ Palmer ${ }^{193}$ In her affidavit evidence, the mother had referred to evidence from another witness in separate court proceedings; extracts from a transcript of oral evidence; and points on appeal and passages from the Family Court judge's decision in the other proceedings. The father had been a witness but not a party to the earlier proceedings filed by his mother seeking appointment as an additional guardian. The evidence from the earlier proceedings was critical of, and no doubt highly prejudicial, to the father.

The father objected to the evidence on the grounds of hearsay; unilateral editing of previous proceedings and judgments; irrelevance and little or no probative value. References to the previous judgment were said to be "published without leave of the Court"194 and a breach of natural justice.

Rule 158 of the Family Court Rules 2002 provides jurisdiction for the court to refuse to read an affidavit that unnecessarily sets forth any argumentative matter or copies of, or extracts from, documents; or is an affidavit in reply, but introduces a new matter. ${ }^{195}$ The first limb

\footnotetext{
$192 \quad$ Evidence Act 2006, s 8.

193 Taylor-Edwards v Palmer [2002] NZFLR 812, (2002) 21 FRNZ 588.

194 Family Courts Act 1980 ss $11 \mathrm{~B}$ and 11C.

$195 \quad$ Family Court Rules 2002 r 158(2).
} 
referring to unnecessarily setting forth an argument must be read as indicating that, if it necessarily sets it forth, it must be relevant.

The Court considered its powers to exclude an affidavit or parts of it under the Family Court Rules and referred to the "any evidence" rule in considering whether to admit the evidence. Judge Mill referred to previous case law and in particular, Nicholls v Nicholls, ${ }^{196}$ Barlow v Barlow, ${ }^{197}$ and Coleman v Coleman. ${ }^{198}$ The Court held that the evidence was not admissible, as it was not relevant to the same issue as in the earlier proceedings; furthermore, it was hearsay evidence and there was no explanation about why the other party to the earlier proceedings was not herself a witness in the present case to avoid the objection about hearsay.

The hearing Judge referred to the offending parts of the affidavit which would need to be excised but ultimately suggested that the affidavit be returned to the applicant and a new affidavit presented excluding those objectionable paragraphs.

(a) Admissibility under the Evidence Act 2006

An application to remove a parent as a guardian requires highly cogent and persuasive evidence that such removal is necessary for the welfare and best interests of the child. It is not an application lightly granted as it can sever the child's relationship with the parent as effectively as adoption.

Some of the contested evidence offered in this case, such as the extracts from the other Family Court judgment, and transcripts from the previous hearing, would still be objectionable under r 158 of the Family Court Rules which must now be interpreted in light of the "touchstones" of ss 7 and 8 of the Evidence Act 2006.

It is not unusual for lawyers to refer to previous court proceedings often filed by a different applicant but with the same respondent. ${ }^{199}$ This is especially common in domestic violence cases and may involve reference to those earlier proceedings of which the applicant is aware. Propensity evidence about past violence will be relevant due to the well-accepted premise that "past violence is the biggest (or most reliable) predictor of future violence", ${ }^{200}$ although how recently the violence occurred and the steps taken to mitigate future violence are also

\footnotetext{
$196 \quad$ Nicholls $v$ Nicholls above $\mathrm{n} 98$.

197 Barlow v Barlow 16/9/98, Judge Inglis QC, FC Christchurch FP009/473/96.

$198 \quad$ Coleman v Coleman 6/8/97, Judge Doogue, DC Auckland FP515/91.

199 And contemporaneous cases involving the same party or parties and which arise out of the same event or transaction will often be consolidated and heard together under r 135 of the Family Court Rules 2002. Surrey $v$ Surrey, above n 6 at [40] and [42].
} 
relevant. ${ }^{201}$ If the evidence from the earlier case was in respect of the same issues which impacted directly on the safety of the child, then it would be more likely to be relevant.

Under the Evidence Act 2006, the hearsay evidence from the father's mother would not be admissible, as while relevant, and presumably made in circumstances providing reasonable reassurance about reliability, ${ }^{202}$ the witness was not said to be unavailable. Given the prejudice likely to be caused by the evidence it is unreasonable to conclude that a trial judge would consider that undue expense or delay would be caused by calling that witness.

The other objection raised was about the earlier court proceedings being annexed to an affidavit in breach of the rule about publishing proceedings. ${ }^{203}$ Given the private nature of Family Court proceedings and the fact that some of the same parties were involved, the argument about publication appears spurious. It is likely that the evidence being proffered through the previous proceedings was propensity evidence or possibly character evidence about the father. As affidavits in the previous proceedings were likely to be hearsay statements, they would not be admissible for the same reasons raised above about hearsay not meeting the specific criteria for inclusion under section 18 .

The conclusions reached about admissibility would not have been any different under the Evidence Act 2006. While the "any evidence" rule provided the Court with a wide discretion to include contested evidence if the court thought it fit to admit, admissibility was still based on the grounds of relevance and reliability, now distilled into Evidence Act principles. The ability of the deponent to have parts of an affidavit excised continues in s 91 of the Evidence Act 2006 which allows a party to edit a statement if it has been ruled as partly inadmissible..$^{204}$

\section{$5 T v G$ - unlawful or irrelevant-use of transcripts of taped conversations}

A witness's affidavit in support of a final protection order in $T v G^{205}$ included transcripts of recorded conversations. This evidence was challenged on two grounds: First, that the evidence had been obtained illegally (and was therefore inadmissible) and secondly that it was not

\footnotetext{
$201 \quad$ See earlier discussion of $D v O$, above $\mathrm{n} 10$.

$202 \quad$ Evidence Act 2006, s 18.

203 Family Courts Act 1980 ss 11 B and $11 C$.

204 Provided the inadmissible parts of the statement can be excluded without obscuring or confusing the meaning of the admissible parts. 
relevant. Judge Riddell assumed that all the tapes were made by the witness in conversations in which she was a party. Therefore, they were not illegal and inadmissible on that ground. ${ }^{206}$

The Judge referred to the "any evidence" rule ${ }^{207}$ in dealing with the second objection that the evidence was "largely irrelevant to the determination of the domestic violence issues," ${ }^{208}$ and it was noted that "there appeared to be no firm principles established at Court of Appeal level to govern the exercise of judicial discretion" 209 to admit evidence in the Family Court. Judge Riddell was guided in her admissibility decision by the rules about the form and content of affidavits ${ }^{210}$ and the inherent power of the Court to regulate its own processes to prevent abuse and ensure that the Court processes are used fairly. ${ }^{211}$ She held that the transcripts of the recordings had a very limited degree of relevance and while one of the reasons they were offered was to resolve credibility issues, there was a risk of self-corroboration such that they "may unfairly bolster the credibility or evidence of the respondent and his witnesses." ${ }^{212}$ The transcripts were excluded from the hearing.

The court also referred to the objects in the Domestic Violence Act 1995 providing for effective legal protection for victims and speedy and inexpensive access to justice. ${ }^{213}$ If the transcripts were admitted, they would add to an already lengthy hearing where proceedings had already been unnecessarily prolonged and delayed.

(a) Analysis under the Evidence Act 2006 alone

Whether the evidence was relevant would depend on whether the transcripts revealed something of consequence to the proceeding and whether they had a tendency to prove or disprove that thing. ${ }^{214}$ The probative limb of s 7 requires an assessment of the value of the evidence. If the content and reliability of the recordings required speculation about whether it had the tendency to prove or disprove a thing of consequence, it could not be said to pass the probative threshold of relevance. ${ }^{215}$

\footnotetext{
206 Crimes Act s 216(B)(2) and s 217 and Evidence Act 2006, s 30. Provided the interceptor is a party to the communication, then the interception is lawful and there is no penalty under s 217 for disclosure of that communication.

207 Domestic Violence Act 1995, s 84.

$208 \quad T v G$, above $\mathrm{n} 205$ at [13].

209 At $[18]$.

$210 \quad$ Rule 158 of the Family Court Rules 2002.

$211 T v G$, above $\mathrm{n} 205$ at [20].

212 At [29].

213 At [31].

214 Evidence Act 2006, s 7.

215 The majority of the Supreme Court in $R v$ Bain [2009] NZSC 16, [2010] 1 NZLR 1 at [42] held that: "...material proffered as evidence is not probative where its connection with the fact to be proved is conjectural only."
} 
There is clearly a risk that audio or video recordings created by a party manipulating a situation by engineering a conversation without the other party's knowledge, may not reveal the truth and could be self-serving. For example, a victim of domestic violence may deny that violence has occurred, depending on who is questioning them (they may deny any domestic violence when speaking to their parents for example). With the prevalence of devices, parties in proceedings are increasingly eager to present their lawyers with recordings asking for these and their transcripts to be admitted. Simply because a statement is recorded does not mean it meets the relevance threshold or is the incontrovertible truth. Much will depend upon context and other reliability factors. ${ }^{216}$

Once a decision is made about relevance under s 7 of the Evidence Act, consideration turns to s 8 of the Evidence Act 2006. Admission of transcripts of doubtful relevance would needlessly prolong the proceedings. The injunction to provide effective legal protection for victims of domestic violence and access to the court which is speedy, inexpensive and as simple as is consistent with justice ${ }^{217}$ would influence the general exclusion exercise in s 8 as it definitively did in this case when the matter was first determined. ${ }^{218}$

\section{Banda v Hart - propensity evidence about behaviour of spouse}

In Banda $v$ Hart $^{219}$ the wife claimed that the equal sharing regime under the Matrimonial Property Act $1976^{220}$ should not apply. Judge Inglis relied on the "any evidence" rule ${ }^{221}$ to admit similar fact evidence from a witness who had also been in a relationship with the applicant which showed his modus operandi of targeting mature women to gain material advantage.

The Zimbabwean applicant had moved to New Zealand with the respondent in 1987 and they married. They separated in 1993 due to domestic violence. The applicant commenced proceedings in 1997 after the parties' divorce and after he had moved to Australia. When the parties had first got together, the applicant had apparently lied that he was an airline pilot. He had made no financial contribution to the purchase of the home and made very little (if any) contribution to the relationship. He had also made unauthorised drawings on the respondent's funds.

Section 13 of the Evidence Act 2006 allows the Judge to examine a document "and draw any inference from it, including an inference as to its authenticity and identity". Note the expansive definition of "document" in s 3 which includes images or sounds or electronically recorded or stored information. Domestic Violence Act 1995, s 5.

$T v G$ above $\mathrm{n} 205$ at [31].

Banda v Hart (1998) 17 FRNZ 667, [1998] NZFLR 930.

Now the Property (Relationships) Act 1976.

Then situated in the Matrimonial Property Act 1976, s 36. 
The Judge found extraordinary circumstances made out so that it would be repugnant to justice to direct equal sharing of relationship property under the Matrimonial Property Act 1976. The third party's evidence would doubtless have bolstered and corroborated the respondent's case and influenced the Judge's assessment of each party and of the interests of justice. Judge Inglis was critical of the husband's veracity and this factor played a part in the ultimate decision.

(a) Analysis under the Evidence Act 2006 alone

Under the Evidence Act, the evidence from the third party could be categorised as propensity evidence as it tends "to show a person's propensity to act in a particular way or to have a particular state of mind..." Such evidence is now able to be offered in a civil proceeding. ${ }^{222}$ As the third party's testimony had a tendency to prove the husband's habit of taking financial advantage of mature women for material advantage, it was relevant.

Arguably, the evidence proffered from the third party was also evidence about the husband's veracity as it tended to show "a motive on the part of the person to be untruthful." 223 Veracity evidence cannot be admitted unless it is "substantially helpful in assessing that person's veracity." 224 However, this evidence is more properly characterised as propensity evidence under the broad definition in s 40 of the Evidence Act.

As this evidence is relevant, the Court must next consider the two-part general exclusion clause in s 8 of the Evidence Act 2006. In this case, while the evidence was undoubtedly prejudicial to the husband, its probative value was high and the effect of the evidence could not be said to have an unfairly prejudicial effect on the proceeding. The wife carried a high evidential burden to make out her case for unequal sharing due to extraordinary circumstances. This made the evidence from the other witness vital to the wife's case and could not be said to needlessly prolong the proceeding. The propensity evidence supported the case for extraordinary circumstances as well as impugning the husband's veracity. It would be admissible using the Evidence Act alone.

\section{Was the "any evidence" rule necessary in those cases?}

The purpose of comparing the outcomes of cases of pre-Evidence Act using only the Evidence Act was to show whether there is continued utility or necessity for the rule. This analysis confirms that vulnerable participants would not be disadvantaged, and relevant evidence would

\footnotetext{
$222 \quad$ Evidence Act 2006, s 40.

223 Evidence Act 2006, s 37(3)(e).

$224 \quad$ Evidence Act 2006, s 37(1).
} 
not be inadvertently excluded if the rule was repealed. The Evidence Act sufficiently fills its purposes $^{225}$ by providing for admission of relevant evidence in a flexible and principled manner. 
This chapter discusses selected cases decided after the Evidence Act 2006 came into force. ${ }^{226}$ There are three purposes to this inquiry. The first is to determine whether the Evidence Act 2006 has had an impact on admissibility decisions overall in the Family Court. The second is to assess whether the added gloss permitting the court to only admit any evidence "that the Court considers may assist it to determine the proceedings" 227 has created a new test so that evidence is scrutinised with more rigour to determine if it meets this threshold for admissibility. Finally, where the rule was cited or relied on whether that reliance was necessary.

The following chapter on reform options will then address whether removal of the rule or alternatively some variation to the rule is needed.

\section{A The impact of the Evidence Act 2006 in the Family Court}

When the Evidence Act 2006 came into force, Family Court practitioners and judges were relatively slow to apply it to proceedings. While a new codified set of evidential rules was now available, the Act was expressly designated as subordinate to any other enactments in cases of inconsistency. ${ }^{228}$ This dilemma had the effect of virtually negating any direct effect of the Evidence Act on family proceedings ${ }^{229}$ and encouraged the Family Court to accept any evidence it thought fit in reliance on the rule which remained disparately scattered throughout various family law statutes.

Judicial and academic opinion was divided as to whether analysis under the Evidence Act was the first step required in an admissibility decision or whether the "any evidence" rule should be applied first, followed by a consideration of the rules in the Evidence Act 2006. ${ }^{230}$

Some important cases lead the way in applying the Evidence Act 2006 to Family Court proceedings while considering how those rules could be reconciled with the apparently antithetical "any evidence" rule. ${ }^{231}$

\footnotetext{
$226 \quad 1$ August 2007.

227 Since 1 April 2014 when s12A of the Family Courts Act 1980 came into operation.

228 Evidence Act 2006, s 5.

229 A criticism also levelled at the Australian counterpart of the "any evidence" rule in s 69ZT of the Family Law Act. See discussion in Patrick Fitzgerald and Michelle Fernando "Has the Less Adversarial Trial Process Abolished the Rules of Evidence" 20(3) Australian Family Lawyer 25.

$230 \quad$ Helen Cull was of the view that the "any evidence" rule should be the first part of the inquiry in her paper "Rules of Evidence in the Family Court" (NZLS Conference Seminar Paper, Wellington, 2009) 155. This approach was also adopted by Judge Smith in FSE v SJH, above n 151. Subsequent High Court case law confirmed the alternative approach.

231 The undermining of "the significance of the Act, and the value of having most of the rules of evidence in one statute" had already been predicted in Parliamentary debates: Above n 101 at 35 [EV5.01].
} 
Radisich $v$ Taylor ${ }^{232}$ was an appeal from an interlocutory decision about the admissibility of affidavit evidence in a relationship property case. The Family Court Judge had referred to ss 7 and 8 of the Evidence Act but noted: 233

...questions of admissibility in the context of PRA proceedings must be viewed through s 36 PRA. ${ }^{234}$

After examining each objection, the High Court excised two offending paragraphs from the affidavits; one relating to an allegation of Mr Radisich's misconduct (an irrelevant consideration in relationship property matters unless the misconduct has affected property);235 the other relating to evidence about Mr Radisich not being able to fund a specific social function. Most of the evidence was permitted to remain so that the trial Judge could assess its relevance when the matter was referred back to the Family Court for hearing. ${ }^{236}$

Courtney $\mathrm{J}$ in the High Court Judge had referred to the "any evidence" rule and previous case law, as if it were a "lens" through which the fundamental principles of the Evidence Act 2006 should be examined. It does not appear that the rule played any part at all in the court's final analysis about admissibility.

In $B P F \vee L T D^{237}$ Judge Boshier dealt with an application to exclude affidavit evidence of disclosures from a counsellor who had been privately contracted to provide family therapy in a care of children case. It was alleged that the children were at psychological risk. Although Judge Boshier made passing reference to the "any evidence" rule, ${ }^{238}$ his analysis of admissibility was based solely on s 69 of the Evidence Act 2006. ${ }^{239}$ He listed the factors relied on $^{240}$ in weighing up the competing public interests, and identified the children's best interests as the first factor, noting: "the therapeutic evidence adduced here raised significant welfare issues for the children". ${ }^{241}$ The "any evidence" rule was not needed to admit relevant and important evidence.

Radisich v Taylor HC Auckland CIV-2007-404-003276, 23 March 2009.

At [5].

The "any evidence" rule previously situated in the Property (Relationships) Act 1976.

Misconduct is generally irrelevant in property relationship matters unless it is conduct which is gross and palpable and significantly affects the extent or value of the relationship property (Property (Relationships Act) $1976 \mathrm{~s} 18 \mathrm{~A}(3)$.

BPF v LTD [Admissibility of evidence] [2010] NZFLR 253.

Care of Children Act 2004, s 128.

Dealing with the overriding discretion as to confidential information.

Under s 69(3) and (4).

$B P F \vee L T D$, above $\mathrm{n} 237$ at [33]. 


\title{
(Non-expert) opinion evidence and business record hearsay
}

In BSH v Ministry of Social Development ${ }^{242}$ the High Court considered an appeal from the Family Court where the Judge had relied on opinion evidence from a social worker, therapist, child psychologist and school teachers, as well as evidence from the intellectually disabled 17 year old ("M17”) and his sister ("S21").

The appeal itself was treated as a general appeal rather than an appeal from an exercise of a discretion. $^{243}$ Dobson J referred to "any evidence" rule ${ }^{244}$ and noted its relevance as a broad discretion: ${ }^{245}$

\begin{abstract}
...but it must be exercised in a principled manner. While the normal rules for exclusion of evidence in the Evidence Act do not apply, due regard must be given to the fundamental tenets of that Act. The reason hearsay and opinion evidence are prima facie inadmissible is because of the increased unreliability of those forms of evidence. Thus, for example, the Family Court ought not to accept hearsay evidence, even though it has the discretion to do so, when it is patently unreliable. Section 195 is not a licence to undermine justice for the purpose of convenience: ...

[29] The entirely appropriate avoidance of unnecessary formality for the Family Court does not permit it to depart from well established principles of the rule of law, and of natural justice, which form an integral part of a fair trial: Hughes $v$ Martin (1983) 2 NZFLR 20 (HC).
\end{abstract}

The evidence about M17's demeanour and the social worker and therapist's perceptions of his veracity met the substantially helpful test ${ }^{246}$ as the veracity of M17 was an important issue and it did not decide the ultimate issue. The witnesses were not being called to provide an opinion about M17's testimony, but about his veracity to tell the truth in the abstract. ${ }^{247}$ The High Court held that this evidence was correctly categorised as expert opinion evidence rather than hearsay evidence but said that, even if the court was wrong about the classification of the evidence as expert opinion evidence, then it could rely on the "any evidence" rule ${ }^{248}$ to admit it. ${ }^{249}$

It is assumed that the witnesses were also communicating what they had saw, heard or otherwise perceived, which had led to them holding particular opinions about M17's veracity. If that were the case, their evidence about those matters would have been able to be provided

BSH v Ministry of Social Development HC Wellington CIV-2009-485-000403, 13 August 2009.

Although other appeals had been dealt with as appeals from an exercise of a discretion due to the permissive language in the rule. See earlier discussion of the rule as an exercise of a discretion in Chapter III.

Children Young Persons, and Their Families Act 1989, s 195.

BSH v Ministry of Social Development, above n 242 at [28] and [29].

Expert evidence may be admitted under s 25 of the Evidence Act 2006 if it provides "substantial help" to the fact finder in understanding other evidence in the proceeding or in ascertaining any fact that is of consequence to the determination of the proceeding.

BSH v Ministry of Social Development, above n 242 at [41].

Then situated in s 195 of the Children Young Persons, and Their Families Act 1989.

BSH v Ministry of Social Development, above n 242 at [42]. 
as admissible opinion in any event, as a witness may state an opinion if it is necessary to enable the witness to communicate, or the fact-finder to understand, what the witness saw, heard, or otherwise perceived. ${ }^{250}$ The "any evidence" rule was referenced as a back-stop in case the court was wrong about the Evidence Act analysis. It had already determined that the evidence was admissible in terms of Evidence Act criteria.

Some commentators argue that the "any evidence" rule is a useful and necessary adjunct to admit viva voce non-expert opinion evidence of parents, as parents can be said to be experts about their own children. ${ }^{251}$ Opinions are usually based on observations the parent has made about what a child has said or done and that evidence of itself could not be said to be objectionable. As noted by Judge Burns: ${ }^{252}$

There must be a distinction between opinions which are the province of an expert and opinions on every day matters or inferences which are obvious from the facts e.g. "it is a nice day" that is an opinion but it is one commonly expressed and an observation from underlying facts like blue sky, no wind, high temperature which the majority of people are able to express based on the underlying facts. That type of opinion is not within the province of a specialist but it is within the province of the majority of people.

Affidavit evidence containing an earlier report from the psychologist was also admitted as documentary hearsay under the Evidence Act 2006.253 However, any objection to the evidence could have been overcome by calling the psychologist for cross-examination. The Judge cited Department of Social Welfare $v T^{254}$ where Judge Inglis held that documentary material should not be treated on any serious or disputed issue as it was an inadequate substitute for oral evidence. Dobson J held that even though oral evidence would have been preferable, this lack did not render the evidence inadmissible as it was relevant under s 7 of the Evidence Act 2006.

Statements from six school teachers about the children's appearance, lack of hygiene, lack of friends and social interactions and disclosures indicating sexual abuse by S13 were also admitted as documentary hearsay. Their evidence was "clearly relevant and provided "substantial help" to the Court. ${ }^{255}$ Only two teachers were called but in the event neither gave evidence. It is likely that the Judge would have found that undue expense or delay would have

$250 \quad$ Evidence Act 2006, s 24.

251 Stephen van Bohemen and Jill Moss "Domestic Violence Act proceedings - New Rigour in Evidence and Proof" (paper presented to the Family Law Conference, Positive Vibes, Dunedin, October 2015) 401.

$252 \quad C v$ M FC Auckland FAM-2006-004-2961, 30 November 2007 at [20(f)].

253 The earlier report had been written some 16 or so years earlier and no useful purpose would have been served by calling the psychologist "having regard to the time that has elapsed since he or she supplied the information and to all the other circumstances of the case". In those circumstances, the psychologist could not be expected to recollect matters and the report must have been admissible: Evidence Act 2006, s 19(1)(b).

$254 \quad$ Department of Social Welfare v T (1988) 4 FRNZ 477.

255 BSH v Ministry of Social Development, above n 242 at [68]. 
been caused if all six teachers were called. ${ }^{256}$ However, their evidence would more properly be characterised as unchallenged admissible affidavit evidence ${ }^{257}$ or by consent. ${ }^{258}$ If a witness is not called to be cross-examined, then the Family Court is entitled to accept that evidence with the only question being about what weight to attribute to the untested evidence.

The Court's reference to substantial help from the teachers' evidence appears to be more a reflection about the reliability of the circumstances in which hearsay statements were made and their combined corroborative effect. ${ }^{259}$ The High Court concluded that s $195^{260}$ does not provide the Court with "licence to disregard" the rules of evidence and instead was indicative of "the emphasis in such proceedings that an overly technical approach should not frustrate the purposes of the Act." 261

\section{Children's evidence}

An alternative approach which used the "any evidence" rule as the first ground for admissibility was favoured by Judge Smith in FSE v SJH: ${ }^{262}$

The alternate view that consideration as to whether or not material is admissible ought first to be by way of resort to the broad ranging discretion afforded the Family Court, as opposed firstly to the more permissible rules of admissibility in the Evidence Act 2006, in my view ought to be preferred but not without caveat.

The two admissibility issues in that case were both about a child's hearsay evidence. The hearsay statements about abuse were reported in an affidavit of the grandfather and in an evidential interview of the child by the police. The respondent sought to have the child called for cross-examination. On that point, Judge Smith concluded that generally calling a child was undesirable but in this case, given the dispute relating to the evidence and the "bizarreness" of the allegation, the child could be called to give evidence but "only if he was willing".

Both admissibility objections could have been overcome using only the Evidence Act. The child's hearsay statement to the grandfather, and the video interview of the child could be admitted if the child was of an age or mental condition (which must include legal incapacity)

\footnotetext{
$256 \quad$ Under s 18(1)(b)(ii) of the Evidence Act 2006.

257 Under s 130 of the Evidence Act 2006 as notice had been given that the affidavits were going to be adduced without calling the deponents as witnesses and no objection was made. In addition, if a witness had been required for cross-examination, written notice would need to have been given under $\mathrm{r} 169$ of the Family Court Rules 2002.

Evidence Act 2006, s 9.

Evidence Act 2006, s 16 defines "circumstances".

The "any evidence" rule.

BSH v Ministry of Social Development, above n 242 at [93(a)].

FSE v SJH, above n 151.
} 
which rendered him unavailable as a witness. ${ }^{263}$ The court would then need to consider the weight of the evidence in the context of the seriousness of the allegation.

A sea change in approach to the interrelationship of the "any evidence" rule with the Evidence Act was heralded by Judge Moss in $O v S^{264}$ where a child's hearsay statement reported in a police officer's affidavit was admitted under s 18 of the Evidence Act as admissible hearsay. The statement was about where the child lived, as both parties alleged the child had mostly lived with them. The court held that the child was unavailable as a witness due to age and commented that: "It is established practice in the Family Court that young children do not give evidence in relation to the central questions in litigation relating to their parenting..."265

\section{Application to admit further evidence - Evidence Act as first consideration}

The application of the Evidence Act rules as the primary basis for admission of evidence in the Family Court was followed by Judge Coyle in $\mathrm{PCH} v \mathrm{AMK} .{ }^{266} \mathrm{He}$ held that the Evidence Act "should now be used as a touchstone by which the standard of evidence should be measured in the Family Court":267

Given that the Evidence Act codifies the law of evidence, the Court's resolution of hearsay should, in my view, be made with reference to that Act. Indeed that was the approach adopted by Judge Moss in $O v S$.

Judge Coyle considered whether the evidence was admissible under the Evidence Act 2006, "but also with reference to the common law doctrines, ${ }^{268}$ and subject to the Court's overarching discretion to admit evidence", ${ }^{269}$ although its discretion to admit evidence "was constrained by what was in the interests of justice in a particular case." 270 The Judge struck out various paragraphs in the mother's affidavit indicating that he had also considered the "any evidence" rule but decided that: "it would not be in the interests of justice, contrary to the welfare and best interests of the children, for the discretion be exercised in the [sic] favour of admissibility...".

Evidence of a new allegation that the father had sexually abused a sibling was admitted, notwithstanding that this was introduced after an earlier hearing and an appeal. The Judge

\footnotetext{
263 According to the definition in s 16 of the Evidence Act 2006.

$264 \quad O v S$ FC Lower Hutt FAM-2008-032-132, 7 April 2008, discussed in Stephen van Bohemen "Evidence: When It's an Issue in the Family Court" (2010) 6 NZFLJ 271.

$265 O v S$, above n 264 at [11]. And see discussion below concerning the case of De Boock v Hoover.

$266 \quad P C H v A M K$ Dunedin FAM-2006-005-000004, 27 May 2011.

267 At $[20]$.

268 At [23]. Under s 12 of the Evidence Act 2006, common law doctrines are preserved in civil matters in a limited way.

269 Pursuant to the "any evidence" rule previously stated in the Care of Children Act 2004, s 128.

$270 \quad P C K \vee A M K$, above n 266 at [19] citing Radisich $v$ Taylor above $\mathrm{n} 232$ at [6].
} 
determined that generally any fresh evidence which sought to re-litigate matters should be struck out on the basis of issue estoppel/res judicata. However, this evidence was admitted on the basis of the "any evidence" rule and the safety principle. ${ }^{271}$ Under the Evidence Act however, it could have been admitted on the basis of relevance as it is without doubt highly relevant whether a parent had possibly sexually interfered with a sibling, as it could be indicative of direct risk to the child. ${ }^{272}$ There is no question that the evidence could have an unduly prejudicial effect on the father as there is a "credible risk of unfair prejudice", ${ }^{273}$ but such a risk could not be said to outweigh the probative value of the evidence given the potential risk to the children. The probative weight would be assessed considering the reliability of the hearsay statement and the credibility of the other witnesses, along with any explanations about the delay in bringing the evidence.

In $M E v V E P N$ and LAJA, Judge Callinicos followed the $P C K$ approach and the paramountcy principle overriding the Evidence Act 2006. He held:274

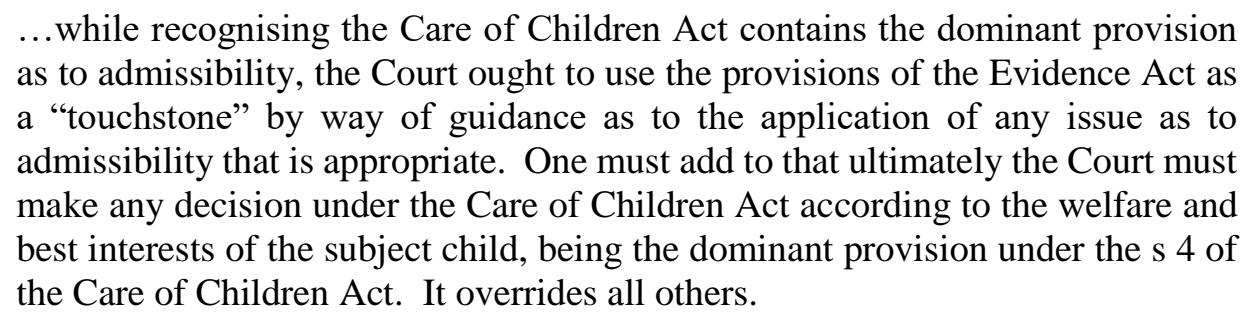

The approach advocated by Judge Moss and taken up by Judge Coyle in $P C K$ is now the approach followed by Family Court judges and the standard mandated in s 12A of the Family Courts Act 1980.

\section{B Is admissibility more limited under the new "any evidence" rule?}

The passing of s 12A of the Family Courts Act 1980 unequivocally clarified any misunderstandings about the primacy of the Evidence Act 2006. This part of the chapter deconstructs selected cases which relied on 12A of the Family Courts Act 1980 to determine if the alteration of priority and preservation of the rule has resulted in greater reliance on the Evidence Act 2006.

The previous "any evidence" rule used permissive language which signalled wide but not

\footnotetext{
271 Previously set out as principle 5(e) in the Care of Children Act 2004 but resituated as s5(a) to accord it primary place (in the 2013 family law amendments).

272 And admissible as propensity evidence under s 40 of the Evidence Act 2006. And see previous discussion about $B v F$, above n 168 .

273 Mahoney and others, above n 101 at [EV8.02] n 344.

$274 \quad M E v$ VEPN FC Napier FAM-2008-041-000481, 1 September 2011 at [26].
} 
unprincipled discretion. The new rule echoes the permissive language, seemingly providing a flexible discretion to the court. However, in Magan v Magan, ${ }^{275}$ Judge Coyle, posited that Parliament had signalled a change by creating a new gateway requiring evidence to be of "assistance in determining the proceedings" before the Court could admit otherwise inadmissible evidence under the Evidence Act. ${ }^{276}$ Despite this pronouncement, there has been scant consideration by the Family Court about whether evidence "assists in determining the proceedings" when relying on the rule.

In a recent case, the High Court expressly referred to the test in s 12A when deciding whether to admit "fresh evidence" of a witness reporting a conversation with his daughter. ${ }^{277}$ The court's analysis indicates that the test requires some assessment about probative value when deciding whether evidence is "of assistance in determining the proceedings". ${ }^{278}$ While the new section has ensured that all admissibility decisions are now considered under the Evidence Act before resorting to the "any evidence" rule, the altered wording does not appear to have changed the threshold for admissibility overall.

\section{Expert opinion evidence}

The High Court in McLay v Ministry of Social Development ${ }^{279}$ considered an appeal from a Family Court decision to exclude an expert psychologist's reports. These had been prepared on instructions from the parents while the psychologist still held a court brief to prepare a court report. ${ }^{280}$ There were concerns about the psychologist being in a position of "irretrievable conflict" and a risk that the integrity of the reports was compromised.

As the Family Court had earlier directed the report, it had already determined that the evidence was going to be substantially helpful. ${ }^{281}$ It was held that as the reports had been directed, the court must have considered they were relevant. However, the High Court held that the "any evidence" rule in s 12A and the low threshold of "may assist," was probably "not much higher than mere relevance." ${ }^{282}$ It admitted the reports on the possibility that they may assist the court to determine the proceedings but the Judge could not comment on the weight to be attached to the views in the report. As these were the only reports supportive of the parents, "in fairness the Court ought to at least consider them." ${ }^{283}$ The question arises whether the court relied on $\mathrm{s}$

"Absence of related detail and the hearsay dimension tell against admissibility of the evidence, the probative value of which is low" (at [32]). McLay v Ministry of Social Development [2014] NZHC 3398.

Under s 178 of the Children, Young Persons, and Their Families Act 1989.

As per the requirement for admissibility of expert's reports under s 25 of the Evidence Act 2006.

McLay, above n 279 at [51].

At [60].
} 
12A unnecessarily to admit the reports. The alternative was to rely solely on ss 7 and 8 as well as s 25 of the Evidence Act.

Expert evidence was admitted in reliance on the "any evidence" rule in Gibb $v$ Watt. ${ }^{284}$ The Family Court held that the accountant's valuation of the debt back from a family trust (identified in the deed as separate property) fell short of providing "substantial help" 285 although it may meet the lower threshold for admission as it "may assist" the court to determine the issues. As the evidence being offered consisted of a set of accounting figures providing for the accrual of interest at different rates on the debt back from the trust, it could be argued that the evidence contained both fact and opinion and "factual evidence from an expert will therefore be governed only by the general rules in ss 7 and 8 , and any other admissibility rules applicable..." ${ }^{286}$ The court had already noted the relevance of the information offered.

\section{Confidential information and domestic violence in relationship property proceedings}

Evidence from a general practitioner, psychotherapist and counsellor was sought in a discovery application in proceedings to set aside a s 21 relationship property agreement in Starr $v$ O'Meehan. ${ }^{287}$ The basis for the application to set aside was that the applicant had been subject to domestic violence from the respondent so that the agreement was unfair and signed under circumstances of duress or undue influence. Judge Lendrum considered the matter in terms of ss 57 and 69 of the Evidence Act 2006. As the parties were not in settlement negotiations and contemplating litigation at the time, the information did not attract privilege. His Honour referred to the court's "overriding discretion" as referred to in the title of the section, and held that the likely harm that may result from the disclosure sought was limited to this case only and limited in respect of the public interest component. Orders were made for discovery of the information from the three non-party witnesses with directions to protect the information ${ }^{288}$ without reference to the "any evidence" rule.

In the later similar case of Brock $v$ Norton, ${ }^{289}$ the husband filed a pre-trial application to exclude inadmissible evidence on the basis that it was irrelevant; would have an unfairly prejudicial effect on the proceedings and needlessly prolong it; and that it did not comply with the rule about affidavits. ${ }^{290}$ The Family Court confirmed that admissibility of evidence in relationship property proceedings was governed by "rules of law" contained in the Evidence Act 2006. The Court specifically quoted Gwaz $e^{291}$ acknowledging that these rules did not confer a discretion

Gibb v Watt [2015] NZFC 5715.

As required for the admission of expert opinion evidence under s 25 of the Evidence Act 2006.

Mahoney and others, above $\mathrm{n} 101$ at [EV25.01(30].

Starr v O'Meehan [2016] NZFLR 409.

Pursuant to the Evidence Act 2006, s 52(4).

Brock v Norton [2016] NZFC 468.

Rule 158 of the Family Court Rules 2002.

Gwaze, above n 102. 
about the admissibility of evidence but prescribed standards to be observed. After the Evidence Act rules were applied, the "any evidence" rule could be considered. The Court considered the paragraphs objected to and concluded that except for one paragraph, the evidence: ${ }^{292}$

...alleges a pattern of behaviour which, under the definition of "domestic violence" in s 4 of the Domestic Violence Act 1995, could well be classified as domestic violence. It suggests that the husband is very controlling of the wife, and leaves open the suggestion that she was powerless to oppose the contracting out agreement. This evidence is, therefore, clearly relevant to the argument being advanced by the husband [about the oral contracting out agreement].

\section{Speculation, unreliability and hearsay}

In Faw v Faw, ${ }^{293}$ the court held that relevance is always the key issue under both the Evidence Act 2006 and s12A Family Court Act 1980 when dealing with objections to the admissibility of 13 affidavits filed after a domestic violence hearing had been vacated on an indication of settlement. The Judge assessed each affidavit having regard to the Evidence Act but also s 12A of the Family Courts Act 1980. Some affidavits were struck out, others admitted, and the inadmissible paragraphs in certain affidavits were excised (such as those that were speculative or double hearsay and unreliable).

An earlier statement made by the applicant to her pastor about being strangled by her husband was excluded as being hearsay. However, this finding is difficult to reconcile with the fact that the applicant was available to be cross examined about the statement which was not hearsay if it was being offered as evidence of the applicant's earlier statement to a third party rather than as proof that the husband had previously strangled the applicant. In the context of domestic violence proceedings, which almost always occur in the privacy of the home and rarely in front of others, an earlier corroborative statement to a third party is both relevant and likely to be helpful. The probative value of the statement is another matter and would depend on the circumstances surrounding the making of the statement and the credibility of the witnesses. While in that case the "any evidence" rule had been utilised, it appears that its function was as a tool to exclude important evidence rather than to admit otherwise inadmissible evidence.

\section{Privilege}

The absence of the Family Protection Act 1955 from the list of Acts subject to s $12 \mathrm{~A}^{294}$ of the Family Courts Act 1980 was noted in Goodwin v Rensford, ${ }^{295}$ a case argued under both the

\footnotetext{
292 Brock $v$ Norton, above n 289 at [26].

$293 \quad$ Faw v Faw [2015] NZFC 2215.

294 The Family Protection Act 1955, s 11 allows the court to accept such evidence of the deceased's reasons for dispositions that it considers sufficient, whether or not the same would otherwise be admissible in a court of law. Goodwin v Rensford [2015] NZFC 2156; [2015] NZFLR 794.
} 
Family Protection Act 1955 and the Property (Relationships) Act 1976 as alternative causes of action. It concerned the admissibility of privileged legal communications sought to be introduced by the respondent which corroborated her de facto relationship with the deceased. The Court held that the negotiations to resolve differences under s 21 of the Property (Relationships) Act 1976 were privileged and inadmissible and there were strong policy considerations to sustain that view. ${ }^{296}$ However, s12A applied and "the policy of preserving privileged communications is overridden by the need in this case to provide the court with evidence from the grave which will assist it in determining the substantive issue." ${ }^{297}$

Since that case was decided, the Evidence Amendment Act 2016 was passed allowing admission in a proceeding of a communication or a document made or prepared in connection with any settlement negotiations or mediation "if the court considers that, in the interests of justice, the need for the communication or document to be disclosed outweighs the need for the privilege." 298

Section 12A was relied on in Arrington v Slater, ${ }^{299}$ (a relationship property case) where the applicant sought disclosure of legal documents relating to the respondent's employment settlement payment and a Trust he had set up which purchased a house some months after separation. The respondent alleged the purchase was funded with a loan from his mother and an advance from the Trust and he maintained that the documents sought were legally privileged.

The Court held that the employment documents were relevant to the status of the monies; but that it was not necessary for the applicant to see an un-redacted copy of the settlement and that the applicant had a sufficient common interest in the legal documents to displace the privilege conferred by s 54 of the Evidence Act 2006. ${ }^{300}$ The court concluded that the employment settlement document could be redacted and admitted, as the evidence would assist the Court in determining the proceedings (in reliance on s 12A). ${ }^{301}$

\footnotetext{
296 Ibid.

297 Goodwin v Rensford above n 295 at [38]. This approach is at odds with the decision in Pallin, above n 21 , which held that the "any evidence" rule could not be used to override rights and duties such as confidentiality and privilege. Amending s 57 of the Evidence Act 2006.

Arrington v Slater [2016] NZFC 5176.

H Ho argues in "Legal professional privilege and the integrity of legal representation" (2006) 9(2) Legal Ethics 163 at 165, that absolute privilege should more properly be narrowed to apply only "where the communication is made with a view to actual or contemplated litigation. Confidential communications between lawyer and client outside this relatively narrow setting should be governed, not by absolute privilege, but by a contextual and less rigid law of confidentiality". And see: B v Auckland District Law Society (2003) 16 PRNZ 722. 
In respect of disclosure of the solicitor's file setting up the Trust and purchasing the Trust property, the Court held that: ${ }^{302}$

In terms of $\mathrm{s} 12 \mathrm{~A}$, the documents may assist the Court in determining the proceedings and the protection afforded by section 54 of the Evidence Act 2006 may be displaced. Nevertheless, I bear in mind the decision of the Court of Appeal in $M v L$ [1997] 3 NZLR 424 where the Court held said that documents which attract legal professional privilege (as a class defined by statute) are protected not only by statute but for public policy reasons. They are exempt from production unless a claim of privilege is not sustained by the Court.

The Court therefore held the view that "the fairest approach was for [the Judge] to inspect the documents, pursuant to $\mathrm{r} 151$ of the Family Court Rules, to determine their relevance and whether the claim for privilege should be sustained". ${ }^{303}$

As the disclosure of the privileged information about settlement negotiations is now be able to be used by the court, ${ }^{304}$ the need to rely on s $12 \mathrm{~A}$ for admission is obviated. However, it would be more pragmatic and accord with principles of fairness to instead have imposed a reverse onus on the respondent to prove how the house purchase had been funded by the new Trust in the face of his refusal to waive privilege. In the absence of clear and incontrovertible proof about the source of the funds, the court could properly draw an adverse inference that the funds consisted of relationship property. There would be no need to rely on s $12 \mathrm{~A}$ or to subvert the strict convention about the sanctity of legal professional privilege.

\section{Overseas protection order as documentary hearsay}

In De Boock v Hoover, ${ }^{305}$ an applicant sought a final protection order after first applying and being granted without notice temporary protection and interim parenting orders. ${ }^{306}$ The admissibility of Court documents from South Africa relating to domestic violence, and hearsay statements from a child were challenged. Under the Evidence Act, the court documents were held to be relevant; their admission would not needlessly prolong the hearing and nor could it be said that their production was unfairly prejudicial to the proceeding. The only issue for the Court to consider was what weight to give the documents. It is noted however that, while the documents could not be offered as proof of previous violence, they could be offered as proof of previous court proceedings about violence.

At [27].

Arrington v Slater, above n 299 at [28].

Evidence Act 2006, s 57(3).

De Boock v Hoover [2015] NZFC 5848.

Ibid. 


\section{Children's hearsay and compellability}

The second challenge to admissibility in De Boock $v$ Hoover was about hearsay statements made by a child to the mother and to lawyer for the child about being slapped on one occasion; of witnessing the mother being hit by the respondent with a broom (when the family still lived in South Africa) and about hearing what she thought was the father hitting her siblings in the next room. The child was not the "subject of the proceedings" which means either that she was a child of the mother only or a child over the age of 16 so that the court proceedings did not apply to her. ${ }^{307}$

Judge Courtney identified the statements of the child as hearsay statements ${ }^{308}$ and examined them in terms of s 18 of the Evidence Act 2006, noting:309

Children are not usually called to give evidence in Family Court proceedings but on a strict interpretation of section 18 of the Evidence Act [the child] is available and it would not be impractical to have her called.

Hearsay evidence from children is frequently introduced through a parent, teacher, social worker, evidential interviewer, lawyer for the child or a psychologist. The principles in the Care of Children Act 2004 require that the Court must take into account children's views ${ }^{310}$ and lawyer for the child has a specific role of ensuring that any views expressed by the child on matters affecting them (and relevant to the proceedings) are communicated to the court. ${ }^{311}$

The same inherent risks of hearsay are amplified with child witnesses, whose evidence may be more unreliable due to memory (an inability to situate themselves clearly in time or place) lack of understanding of what it was that was seen or heard, or contamination (intentional or otherwise) from other persons. ${ }^{312}$ Children's evidence will often be reliable and cogent but much will depend upon the age of the children and their own cognitive and psychological development. It is well understood that the experience of being a witness is stressful for children, ${ }^{313}$ and calling a child to bear witness against a parent may well cause irreparable harm to family relationships. Despite the destructive and divisive nature of Family Court

\footnotetext{
$307 \quad$ Care and contact orders under the Care of Children Act 2004 do not apply to a child over the age of 16. The comments of the judge indicate that the child was of an age or capacity where she was "available". Under s 4 of the Evidence Act 2006.

De Boock, above n 305 at [60].

Care of Children Act 2004, s 6(2).

Family Courts Act 1980, s 9B(1)(b). Children's evidence and views can also be obtained through judicial interviews (Family Court Rules 2002, r 54).

312 John Spencer and Rhona Flin The Evidence of Children: The Law and Psychology (Blackstone Press, Great Britain, 1990) at 220, where the dangers of evidence when children are being cross-examined after considerable delay, and the risk of evidence distortion from repeated questioning is compared with the preference of pre-trial interviews where such problems are avoided (hereinafter Spencer and Flin). Spencer and Flin, above n 312 at 220.
} 
proceedings, conciliation should always be the goal for the Family Court. ${ }^{314}$ Children should not generally be summonsed to be cross-examined about their hearsay statements for the strong policy reason that this is against their best interests and welfare. ${ }^{315}$ Those same policy reasons apply to older children. ${ }^{316}$ The Children, Young Persons, and Their Families Act 1989 provides for children to give evidence in care and protection proceedings, ${ }^{317}$ but cases where a child is called are rare. There is a significant tension which arises where, as in FSEvSJH, ${ }^{318}$ serious allegations are made against a parent which cannot be tested by cross-examination of the child.

If a child is of an age or capacity where they could be considered available, the court should consider whether they are compellable witnesses. ${ }^{319}$ While they are likely to be strictly compellable according to the broad provision in s 71 of the Evidence Act 2006, ${ }^{320}$ there are strong reasons why children should not be compellable in Family Court proceedings regardless of their age. Legislative provisions giving the court a discretion to excuse a witness for nonattendance on the basis of "just excuse" or "sufficient cause" are inconsistent with the Evidence Act 2006 and will prevail in the face of this inconsistency. ${ }^{321}$ If the child is excused from testifying under a legislative provision allowing the court to excuse them, ${ }^{322}$ they are noncompellable in a de facto sense: ${ }^{323}$

In practical effect, they [the witness summons rules] may operate as a discretionary, broad-based and judicially administered rule of witness noncompellability in civil and criminal trials. However in light of s 71's clear mandate of universal witness eligibility and compellability, judges will undoubtedly hesitate to exercise their discretion to exempt a witness from testifying for what at first glance might appear to be just or sufficient reasons....Excusing a witness from giving evidence may also amount to a finding of non-compellability for the purposes of s 16(2)(e) - one of the provisions in $\mathrm{s}$

314 Lawyers have an obligation to promote conciliation. This responsibility is set out in s 9A of the Family Courts Act 1980.

315 C Murray Earl "Can George (aged 12) tell the court his story? - Children's evidence in the Family Court" (2017) 18(2) Family Advocate 12.

316 Although some minor children are now able to become parties in proceedings without a next friend or litigation guardian: Family Court Rules 2002, r 90A.

317 Such as occurred in BSH v Ministry of Social Development, above n 242. The Children, Young Persons, and Their Families Act 1989, s 167 provides for the child or young person to give evidence in private if the Judge thinks it desirable.

$318 \quad F S E v S J H$, above $\mathrm{n} 151$.

319 Another ground of unavailability for hearsay evidence under s 16 of the Evidence Act 2006. Prima facie any person who is eligible to give evidence is compellable to give evidence. For discussions of children as compellable witnesses see JLE $v$ JAR-B [Protection order [2013] NZFLR 1 at [51]-[61] and FSE $v$ SJH, above n 151.

320 Which creates a presumption of eligibility and compellability as the section states that in a civil or criminal proceeding any person is eligible to give evidence and a person who is eligible to give evidence is compellable to give that evidence. This applies regardless of age.

$321 \quad$ Evidence Act 2006, s 5.

322 For a discussion about excusing a witness from testifying see Mahoney and others above $\mathrm{n} 101$ at [EV71.05]. Section 102 of the District Courts Act 2016 provides a defence of "reasonable excuse" for failing to answer a witness summons. There does not however appear to be a similar provision to excuse a witness from a summons issued under $\mathrm{r} 50$ of the Family Court Rules 2002. Mahoney and others, above n 101 [EV71.05]. 
16(2) that sets out the definition of a person being "unavailable as a witness" under the Act's hearsay rules.

However a witness summons can be issued in the Family Court under $r 50$ of the Family Court Rules 2002. Under that rule, there is no provision for a payment of fine or other penalty for non-attendance and the witness must be offered witness fees and expenses. As there is no apparent penalty for failure to comply with the witness summons there is no defence built into that provision. If a witness objects to coming to court to provide evidence, they can apply for the witness summons to be set aside. This is a considerable amount of complicated legislative machinery that comes into play if all children are potential witnesses. This would require children to be summonsed, so that they can only become non-compellable if their witness summons is set aside.

If the child is not compellable, despite being of an age or capacity where they may be considered available, then the hearsay provisions in the Evidence Act can be used to admit the child's hearsay evidence without requiring the child for cross-examination. In the absence of a finding that the child is non-compellable, there is no way to allow the older child's hearsay evidence to be admitted other than by the "any evidence" rule. If the evidence is admitted without the opportunity for a party to cross-examine, then the court will need to carefully assess issues of weight and reliability. If the child is called to be cross-examined, then the court will need to consider the process of that examination, and the Evidence Act 2006 provides alternative ways for a child to give evidence if they are called as witnesses. ${ }^{324}$ An older child may wish to give evidence, but this too gives rise to policy considerations around best interests and well-being even of older children.

\section{Veracity evidence}

In Gebrien v Todd ${ }^{325}$ Judge Moss considered the issue of veracity evidence where the mother made a rape complaint against the applicant father some months after the mother's first notice of defence was filed. A decision about the truth of this allegation was required because of its relevance to the safety of the father having unsupervised care or contact with his child. ${ }^{326}$ Judge Moss discussed reliability and credibility and referred to the "substantially helpful" test that must be passed before opinion evidence about veracity could be admitted under s 37 of the Evidence Act 2006. The decisions about admissibility were made by relying explicitly on the Evidence Act principles, although her Honour commented that she had allowed greater latitude in the hearing of viva voce evidence in relation to opinion and context because of the nature of

324 And these provisions apply to civil as well as criminal proceedings (Evidence Act 2006, ss 103-105).

$325 \quad$ Gebrien v Todd [2015] NZFC 4949.

326 Compare this decision with the earlier decision of $B v F$ where the court also had to rule about the relevance and admissibility of a rape allegation in a child contact case (above $n$ 168). 
proceedings where witnesses were describing matters of "acute distress and profound importance to them personally." 327

\section{Section $12 A$ as last resort only}

The requirement to comply with the Evidence Act rules was robustly re-affirmed by Judge Coyle in Marsden v Bernard ${ }^{328}$ with an implication that the "any evidence" component of section $12 \mathrm{~A}$ was only available as a last resort:

Much of the evidence of Ms Marsden is, however, rank hearsay and is evidence that would be entirely inadmissible under s 17 Evidence Act 2006. Given that s 12A Family Courts Act 1980 requires that all evidence before the Court must now comply with the Evidence Act it is unclear to me why such rank hearsay has been included in this application. In saying that, as I have already acknowledged, there are some elements of Ms Marsden's evidence which do need to be carefully and squarely confronted by the Court when considering the welfare and best interests of [the child].

\section{Conclusion - is the "any evidence" rule still needed after the Evidence Act 2006?}

The "any evidence" rule continues to be referred to in admissibility decisions, but most often unnecessarily. Practitioners do not consistently apply the Evidence Act 2006 despite the injunction in s 12A of the Family Courts Act 1980 that it is to apply to proceedings. It is easy for practitioners to overlook the Evidence Act when drafting documents, particularly under urgency. ${ }^{329}$ The increasing number of self-litigants add to this evidentiary chaos and culture of free evidence.

The court addresses transgressions to evidential rules either when evidence is challenged or alternatively when it is so glaringly inappropriate that it deserves comment, ${ }^{330}$ and in those cases, it applies the Evidence Act to determine admissibility with occasional reference to $\mathrm{s}$ 12A. While there is still reasonably frequent reference to the "any evidence" rule there are few cases when it has been needed. By and large, it has been utilised unnecessarily as a just-incase mechanism in the event of doubt about admissibility under the Evidence Act 2006.

There have been a limited number of situations identified where the Evidence Act did not adequately provide for admission of relevant evidence in order to protect the vulnerable parties to disputes. These instances where the rule was explicitly relied on are: where legal privilege

\footnotetext{
327 Gebrien v Todd, above n 325 at [32].

$328 \quad$ Marsden v Bernard [2016] NZFC 4730 at [14].

329 And the vast majority of applications are now drafted and filed without notice under urgency. See above n 105.

$330 \quad$ See for example the comments in Marsden $v$ Bernard above $\mathrm{n} 328$.
} 
has prevented access to important information about assets of the other party; ${ }^{331}$ where the existence of a de facto relationship could not be proved without disclosure of legally privileged negotiations relating to a previous relationship property deed; 332 where opinion evidence of non-experts was admitted to provide context about the veracity of a witness; ${ }^{333}$ and where hearsay evidence from a child could not otherwise be admitted as she was clearly of an age or capacity where she was "available" as a witness. ${ }^{334}$

In the cases dealing with legal privilege, admissibility issues could be overcome as signalled earlier by using the amended rules about disclosure of privileged material ${ }^{335}$ or by imposing a reverse onus on the non-disclosing party. ${ }^{336}$ Parties will be clearly disadvantaged if the more powerful party is able to hide behind legal privilege to avoid providing disclosure of information about assets over which the disadvantaged party may have a claim.

Hearsay evidence will usually be admissible in without notice applications (although weight is another issue) due to the undue delay that would be caused by requiring the maker of the statement to provide evidence first hand. Any objections taken to those hearsay statements can almost always be overcome by having those statement makers called as witnesses if the evidence is disputed. In the absence of an objection about hearsay statements, the evidence can be admitted by implied consent under either s 9 or under s 130 of the Evidence Act. ${ }^{337}$

The final matter unresolved remains the issue of children's evidence. While younger children are unavailable because of age or capacity allowing their hearsay evidence to be admitted, this basis is not available for older children. The argument that a child witness is unavailable due to non-compellability if their appearance is excused by the court ${ }^{338}$ provides an uncertain solution based on judicial discretion. In the absence of the "any evidence" rule, issues arise with children who are of an age where they could be considered available and competent. ${ }^{339}$ The Family Court has used the "any evidence" rule to protect children and receive their evidence in a way that harms them least. The rule has served a useful purpose in allowing the admission of evidence from children of all ages.

\footnotetext{
Arrington v Slater, above n 299.

Goodwin v Rensford, above n 295.

Gebrien v Todd, above n 325.

De Boock v Hoover, above n 305.
}

Section 57 of the Evidence Act 2006 permits some limited disclosure of privileged information.

Alternatively, the rule about absolute privilege could be limited (see above n 300).

In conjunction with $\mathrm{r} 169$ of the Family Court Rules 2002 requiring a party to give written notice if a deponent is required for cross-examination at hearing.

See above discussion at $\mathrm{n} 322$.

On the basis of Gillick competence. Gillick v West Norfolk Area Health Authority [1986] 1 AC 112 (UKHL). 
The associated issue of compellability of children as witnesses is a complex one. It requires careful balancing of competing rights, the need to protect children from further exposure to adult conflict and the desirability of using a discretionary back door mechanism to create noncompellability. This issue is likely to confront the Family Court increasingly in the currently developing rights-based climate where parents may demand to have the child cross-examined in order to uphold "their right" to a fair trial. Against this background, it would be preferable to have clear legislative policy dictating whether children of any age should be called as witnesses in Family Court cases. 
The chapter provides a brief review of family law evidence rules in England and Wales and in Australia. These jurisdictions are reviewed for the purpose of identifying common themes and approaches that may be helpful in New Zealand given our shared legislative histories and social norms. However, a clear distinction must be drawn between those jurisdictions and the unique evidential framework now provided by the Evidence Act 2006.

Options for reform are discussed which best meet the dual purposes of protecting vulnerable participants by ensuring that essential information is admitted without simultaneously allowing the untrammelled introduction of extraneous evidence.

Revocation of the rule is the most obvious solution to meet these purposes, but other less radical reforms are considered, including limiting the operation of the rule and adopting procedures to improve the overall standard of evidence in the Family Court.

\section{A Comparative Jurisdictions - England (and Wales) and Australia}

In England and Wales there is no comparable "any evidence" rule for family proceedings. Section 96 of the Children Act 1989 provides for the admission of children's evidence where a child ${ }^{340}$ does not understand the nature of the oath but understands the duty to speak the truth and has sufficient understanding to justify their evidence being heard. ${ }^{341}$ Section 2 of the Children's Evidence (Admissibility of Hearsay) Order 1993, provides for the admission of children's hearsay:

\section{Admissibility of hearsay evidence}

In- (a) civil proceedings before the High Court or a county court; and

(i) family proceedings, and

(ii) civil proceedings under the Child Support Act 1991 in a magistrates' court, evidence given in connection with the upbringing, maintenance or welfare of a child shall be admissible notwithstanding any rule of law relating to hearsay.

The Order prescribes something like the "any evidence" rule but specifically and only in relation to hearsay evidence, and only in proceedings relating to children. The order itself does

\footnotetext{
340 In England, Wales, Northern Ireland and Scotland, for child protection purposes, a child is anyone under the age of 18. (<www.nspcc.org.uk/preventing-abuse-child-protection-system/legal-definitions-childrights-law/legal-definitions $>$ ). This definition is consistent with UNCROC where a child is defined in Article 1 as a person below the age of 18 . provision for the admissibility of evidence which would otherwise be inadmissible under any rule of law relating to hearsay.
} 
not appear to limit the hearsay evidence to hearsay statements from the child only, although the title to the Order suggests it is so limited. ${ }^{342}$

In Australia, the "any evidence" provisions ${ }^{343}$ in s 69ZT Family Law Act 1975 were enacted as part of the Division 12A reforms promulgated with the wider 2006 family law reforms. Division 12A was designed to provide a less adversarial trial process ("LAT") and sets out five principles for conducting child-related proceedings in section $69 \mathrm{ZN}$ which can also apply to other types of family proceedings if the parties consent. These principles are both directive and ambitious:

1. The court must consider the needs of the child concerned and the impact of the conduct of the proceedings on the child;

2. The court is to actively direct, control and manage the conduct of the proceedings;

3. The proceedings are to be conducted in a way to safeguard the child against family violence, child abuse and neglect and the parties against family violence;

4. The proceedings are to be conducted in such a way so as to promote co-operative and child-focused parenting;

5. Proceedings are to be conducted without undue delay and with as little formality, legal technicality and form, as possible.

Section 69ZT is a natural extension of the principles outlined in Division 12A and is similar to the "any evidence" rule. The court can give "what weight it thinks fit" to the evidence admitted, ${ }^{344}$ and ordinary rules of evidence are applied only as an exception. Section 69ZU provides for evidence of opinions of family consultants to be admissible only if sworn as evidence. In New Zealand the role of reporting a child's views and providing an opinion about best interests is taken by lawyers for children who provide reports on children's views rather than sworn testimony. Section 69ZV provides for "Evidence of children" and specifically permits the admission of children's hearsay evidence if it is relevant to the welfare of the child or another child. A child is defined as a person under the age of $18 .{ }^{345}$

When the "any evidence" rule in Australia was first enacted in 2006, there were concerns ${ }^{346}$ that the rule was revolutionary and would have the effect of abolishing the rules of evidence; that the paramountcy principle and s69ZT would together operate to override the Evidence Act

\footnotetext{
342 In the United Kingdom reform of children's participation in family proceedings is underway. See the draft Family Proceedings Amendment Rules 2017 and Draft Practice Direction were released for consultation in early 2017 (<www.researchingreform.net/2017/02/28/the-buzz-136>).

343 Section 69ZT Family Law Act 1975 enacted as part of the reforms in the Family Law Amendment (Shared Parental Responsibility) Act 2006 (Cth).

$344 \quad$ Family Law Act 1975, s 697T(2).

345 There is no specific definition of child but s $65 \mathrm{H}$ of the Family Law Act 1975 states that a parenting order must not be made for a child 18 or over or who is or has been married or in a facto relationship. Patrick Fitzgerald and Michelle Fernando, above n 229.
} 
1995 (Cth); that s 69ZT would allow poor quality evidence to be submitted and that s 69ZT would allow lawyers to present evidence in a sub-standard manner. To some extent, those concerns $^{347}$ have been borne out. In a review of the 2006 reforms undertaken in Australia, ${ }^{348}$ there were mixed responses to the Division 12A reforms. The flexibility of s 69ZT was mostly welcomed by judges. Some were concerned about the poor quality of affidavit material, although most agreed that their discretion as to weight was sufficient to deal with "dubious evidence" being put before them. ${ }^{349}$ Lawyers were the most negative about the new rules with: 350

Evidence coming before the court which is suspect. Parties and lawyers and judges think that almost anything is relevant. Professional standards are falling as a consequence.

A further quote in the report refers to unnecessary and irrelevant material being included in affidavits "because there is no one to stop [sloppy or incompetent lawyers]. This usually has the effect of escalating tension". ${ }^{351}$ The adoption of the LAT process as part of the suite of family law reforms has had some positive benefits. More active judicial management was considered helpful, although inconsistencies in practices, along with more court events and higher costs were identified as problematic. ${ }^{352}$

In England and Wales and Australia, the notable commonality is that the exception to the ordinary rules of evidence is limited to children's cases (although the rules can be extended to other family proceedings by consent in Australia). The United Kingdom limits this flexibility further by confining the exception to children's hearsay only and no leeway is given for admission of other types of evidence. Children are defined in those jurisdictions as persons under the age of 18 .

In New Zealand, younger children's hearsay is admissible under the Evidence Act 2006 because of their unavailability due to age or capacity. Other children are compellable but the "any evidence" rule currently fills the gap to permit the Family Court to admit their hearsay evidence if the court considers it "may assist". Relying on a judicial discretion contains significant risks of an uneven and inconsistent approach from the court. Providing statutory certainty about non-compellability of older children would be a preferable solution. This would require the legislature to make transparent policy decisions having weighed up the competing issues of natural justice rights for a person or parent against whom an accusation is levelled, the need to test scandalous allegations of older children, and to protect children from

\footnotetext{
$347 \quad$ Patrick Fitzgerald and Michelle Fernando, above n 229, 25.

348 Rae Kaspiew and others Evaluation of the 2006 Family Law Reforms (Australian Institute of Family Studies, Melbourne, December 2009).

$349 \quad$ At $[14.3]$.

$350 \quad$ At $[14.3]$.

$351 \quad$ At $[14.3]$

352 At [14.3.2-14.3].
} 
the damaging nature of family court processes and the relevance of the criminal/civil distinction.

\section{B Reform proposals}

Various options for reform of the "any evidence" rule were considered in the policy work leading up the 2014 family law amendments in New Zealand. Repeal of the "any evidence" was considered as one option for reform. ${ }^{353}$ Other options included amending the rule so that evidence would not be admitted unless "the interests of justice" made it appropriate to receive otherwise inadmissible evidence. But this threshold was thought to be too high so that contextual information might be (unhelpfully) omitted from applications. ${ }^{354}$

One case identified in the research for this dissertation highlighted the risk that in the absence of the "any evidence" rule, evidence of an older child deemed to have capacity may not be able to be provided as hearsay evidence. The conclusions reached in this dissertation suggest that the most logical reform option is to revoke the "any evidence" rule so that the Evidence Act 2006 governs admissibility in all instances. A less radical reform would be to limit the "any evidence" rule to either children's cases or children's hearsay. However, it is questionable whether these more moderate reforms would alleviate the defects caused by the rule. Other legislative and procedural suggestions that may improve the quality of evidence in the Family Court are also discussed below.

\section{Revoke the rule}

An over-abundance of caution may suggest that outright repeal of the rule, with no alternative in place, may result in unintended draconian consequences, especially for children. It is this unknown factor which prevented the rule being revoked in the overhaul of family law in 2013.355 No legal reformer or theorist would wish to recommend legislative change which resulted in harm to children or other vulnerable parties by the inadvertent exclusion of important evidence. Yet the Evidence Act 2006 already provides a broadly inclusive definition of relevance capturing anything which may have a tendency to prove or disprove "anything of consequence" to the determination of the proceeding, as well as permitting hearsay and opinion evidence in a wide range of circumstances.

\footnotetext{
353 Ministry of Justice Improving the quality of initial court processes and evidence (Policy work undertaken by the Ministry of Justice, obtained under an Official Information Act 1982 Request to the Ministry of Justice February 2016).

$354 \quad$ Ibid.

355 Ibid. It was considered that repealing s 128 (the "any evidence" rule in the Care of Children Act 2004 "may be detrimental to children's interests".
} 
The advantage of repealing the rule is that a consistent set of rules would apply across all family proceedings, ${ }^{356}$ evidential issues would be clarified and process fairness would be restored so that the interests of justice are met. As the rule has been shown to operate against the best interests of the very persons it was intended to assist, repeal or amendment is a positive and necessary step towards righting that misalignment. The disadvantage of outright repeal is that there is a small class of cases where the rule may be of benefit. Relying on the complicated backdoor method of establishing non-compellability by not requiring the attendance of an older child witness is unsatisfactory and will not result in a consistent resolution of the issue.

Repeal of the "any evidence" rule could be effected by revoking the second part of subsection 4 of s 12 A of the Family Courts Act 1980 which reads:

However, the court hearing the proceeding may receive any evidence, whether or not admissible under the Evidence Act 2006, that the court considers may assist it to determine the proceeding.

This would leave the first part of subsection 4 intact confirming that the Evidence Act 2006 applies to the proceedings listed in that section. An even more satisfactory solution would be to replace s 12A with the simple statement that: "The Evidence Act 2006 applies to all Family Court proceedings."

\section{Revoke the rule and amend the Evidence Act 2006 definition of availability}

A supplementary approach to repealing the "any evidence" rule would be to amend s 16(2) of the Evidence Act 2006 at the same time so that in civil proceedings, a child ${ }^{357}$ is not available as a witness. This consequential amendment would resolve the issue of older children's hearsay evidence by the insertion of a new paragraph (ca) as proposed below:

For the purposes of this subpart, a person is unavailable as a witness in a proceeding if the person-

(a) is dead; or

(b) is outside New Zealand and it is not reasonably practicable for him or her

to be a witness; or

(c) is unfit to be a witness because of age or physical or mental condition; or

(ca) is a child in a civil proceeding; or

(d) cannot with reasonable diligence be identified or found; or

(e) is not compellable to give evidence.

\footnotetext{
356 The rule would also need to be revoked where it has been left in individual statutes such as the Mental Health (Compulsory Assessment and Treatment) Act 1992, the Intellectual Disability (Compulsory Care and Rehabilitation) Act 2003 and the Family Protection Act 1955. Already defined in the Evidence Act 2006, s 4 as a person under the age of 18.
} 
If there was a concern that broadening the exception to all civil proceedings rather than just those in the Family Court was unjustified, the definition in paragraph (ca) proposed above could be further limited to read: (ca) is a child in Family Court proceedings.

All children regardless of age would be unavailable so that their hearsay evidence could be admitted without calling the child to be cross-examined. ${ }^{358}$ That hearsay statement would need to be weighed against all the other evidence available. Butler-Sloss LJ commented on the weighing up exercise in Re W (Minors)(Warship: Evidence): 359

The weight which he [the Judge] places upon the information is a matter for the exercise of his discretion. He may totally disregard it. He may wish to rely upon some or all of it. Unless uncontroversial it must be regarded with great caution. In considering the extent to which, if at all, a judge would rely on the statements of a child made to others, the age of the child, the context in which the statement was made, the surrounding circumstances, previous behaviour of the child, opportunities for the child to have knowledge from other sources, any knowledge, as in this case, of a child's predisposition to tell untruths or to fantasise are among the relevant considerations.

The amendments proposed would not prevent an older child giving evidence if they choose to do so, ${ }^{360}$ but would allow their views to be received without requiring their attendance. ${ }^{361}$ There are already ample ways that a children's hearsay evidence can be brought before the court, including statements made to other adults or to professionals involved in the Family Court process, including judges, ${ }^{362}$ or by the Family Court viewing video recordings of a child's evidential interview in cases of serious abuse or neglect. ${ }^{363}$

A further advantage of this proposed amendment is that it provides consistency across the different courts and avoids further exceptions to the Evidence Act being created in other enactments. For criminal matters, a child would still be available and eligible as a witness when required given the gravity attaching to criminal proceedings.

\section{Limit the rule to cases involving children or children's hearsay evidence only}

(a) Limit the rule so that the test is the child's best interests and welfare Although the definiton of child for this purpose may need to exclude married or partnered children due to their otherwise apparent maturity.

$359 \quad \operatorname{Re} W$ (Minors) (Wardship: Evidence) [1990] 1 FLR 203.

360 In either a parenting or a care and protection case. Section 167 of the Children, Young Persons, and Their Families Act 1989 would continue to allow a child to give evidence in private. Guaranteeing their right to have their views heard and taken into account (as articulated under UNCROC and provided for under s 6 of the Care of Children Act 2004 and s 11 of the Children, Young Persons, and Their Families Act 1989). 
There is no justification for relying on the "any evidence" rule in relationship property matters or matters where children are not involved. Relationship property proceedings, which can also be transferred to the High Court for resolution, are regarded as civil proceedings with the "any evidence" rule an anathema. Other Family Court cases dealing with vulnerable participants ${ }^{364}$ should be able to be dealt with adequately without the "any evidence" rule. In those cases, evidence of instructions or views from the vulnerable person are provided through counsel and can be admitted as hearsay evidence as the witness is unavailable by reason of incapacity. Reported comments from other third party family members or other sources would normally be admitted as non-contentious and admissible by consent, with the witness being called in the event of any disputes about the information included.

If the rule is to be retained at all, it should be limited to children's cases and only when it is demonstrably in the child's best interests to admit the evidence. Such a limitation would mean that even in domestic violence cases the "any evidence" rule could operate if it was in the child's best interests. As there is no discernible reason why some, but not all, family law statutes are subject to s $12 \mathrm{~A}$ of the Family Courts Act 1980, any re-drafting could ensure the application of the rule is even more universal as follows: ${ }^{365}$

(1) The Evidence Act 2006 applies to all Family Court proceedings.

(2) However, the court hearing the proceeding may receive any evidence, whether or not admissible under the Evidence Act 2006, that it is in the best interests and welfare of a child to admit.

The pitfall is that such a minor amendment to the rule may only serve to perpetuate the problem inherent in the rule, namely the free for all approach to admissibility of evidence in the Family Court. The rule in its proposed amended form above is still unsatisfactory as it continues to negate the due process protections provided in the Evidence Act 2006. It would provide little advance from the existing test requiring the additional evidence to "assist the court determine the proceeding". Lawyers and judges will still need a major shift in mindset to avoid the routine admission of inadmissible evidence given that almost anything can be justified as being relevant to the child's welfare and best interests. ${ }^{366}$

\section{(b) Limit the rule to children's hearsay only}

Another less radical option is to limit the rule to children's hearsay in the Family Courts Act 1980. If the gap needing to be addressed is only about children's hearsay evidence, then it

\footnotetext{
364 For example proceedings under the Protection of Personal and Property Rights Act 1988, or under the Mental Health (Compulsory Assessment and Treatment) Act 1992.

365 This, and the following proposed amendment, retain the "list" of specified statutes subject to the rule in s 12A, when in fact there appears no justification for this rule not applying to all statutes administered by the Family Court.

See above criticism arising from the "any evidence" rule in Australia, above n 348 and n 350.
} 
would be preferable that this is what is specifically targeted. Children's evidence could continue to be produced through hearsay statements from parents, teachers, social workers and lawyers, with the same considerations about reliability. However, this hearsay evidence would also be available in other proceedings (such as domestic violence proceedings when a child may report what they have witnessed). A re-formulation of s $12 \mathrm{~A}$ of the Family Courts Act 1980 specifically providing for children's hearsay could read:

(1) The Evidence Act 2006 applies to all Family Court proceedings.

(2) However, the court hearing the proceeding may admit any hearsay evidence of a child that the court considers may assist it to determine the proceeding, whether or not admissible under the Evidence Act 2006.

However, children's hearsay evidence is already able to be admitted under the Evidence Act 2006 and only compellable children's hearsay cannot be admitted. ${ }^{367}$ Unless the child is defined in the Family Courts Act 1980 as "being a person under the age of 18", then the "improved" formulation does nothing to fill the lacuna.

In conclusion, the most satisfactory reform option involves repeal of the "any evidence" rule with a consequent amendment to the list of unavailable witnesses in the Evidence Act 2006 to include "a child in a civil proceeding" or more specifically "a child in a Family Court proceeding".

\section{Other procedural reforms which may assist}

There are other additional measures which singly or together may improve the quality of Family Court evidence and court efficiency overall. These proposals are outlined below.

\section{(a) Require hearsay to be remedied after a without notice application if objection raised}

One of the proposals made in the review of the Family Court leading to the 2013 amendments was that there should be a time limit to file direct evidence when hearsay evidence was first filed in support of an application, including an urgent application under the Care of Children Act 2004 or the Domestic Violence Act 1995. ${ }^{368}$ This suggestion makes sense given that most Family Court applications are made under urgency so that direct evidence cannot always be obtained. Requiring the respondent to give notice to remedy the hearsay may be more sensible as there are cases where no defence or response is ever filed and automatic remedying of hearsay in those cases would be wasted time and expense.

\footnotetext{
367 Under r 50 of the Family Court Rules 2002. See earlier discussion and n 323.

368 Reviewing the Family Court: A public consultation paper, above n 65.
} 
The requirement to remedy inadmissible evidence once urgency has abated is a way of ensuring fairness is restored to proceedings and the quality of evidence is improved for final decisionmaking. This safeguard is particularly important considering the large number of without notice applications currently being made in the Family Court as these potentially cause ongoing injustices. ${ }^{369}$ There will be some instances where, on analysis, the evidence offered may in fact be admissible under the more expansive grounds available in the Evidence Act 2006. Parties could file submissions about this via memorandum if the hearsay was still sought to be admitted without the witness providing direct evidence of the statement.

If the hearsay evidence is not able to be remedied, then ideally the Court should re-examine the original application immediately to consider if there is a sufficient evidential platform on which to continue the temporary or interim orders or whether they should be discharged.

A disadvantage of this approach is that requiring one party to file an objection and the other to remedy the hearsay requires a proactive action by each party. If one or both parties are unrepresented, there is little likelihood of these steps being undertaken. Unless there is active case management by a judge or registrar to explain, monitor and enforce these steps, the hearsay evidence would remain un-remedied for the final decision,.

\section{(b) Revoke the "any evidence" rule and allow lawyers to act}

Another reform that would quell the proliferation of inadmissible evidence would be to repeal s 7A of the Care of Children Act 2004 so that participants can have legal representation from the outset creating fewer self-litigants. Parties could instruct lawyers who would draft all court proceedings. While lawyers are also guilty of filing inappropriately inadmissible evidence, they have been enabled to do so because of the existence of the "any evidence" rule. Lawyers are better equipped than self-litigants to understand and apply the law and present evidence in a proper way ensuring that affidavits are more focused while irrelevant and inflammatory material is excluded. It is easier for the court to gain compliance from lawyers than selflitigants when it comes to procedural and interlocutory matters. Allowing legal representation from the commencement of proceedings would increase Family Court efficiency overall and equalise the balance when one party is more articulate or holds more power. ${ }^{370}$

\footnotetext{
$369 \quad$ See above n 105.

370 If $\mathrm{s} 7 \mathrm{~A}$ is repealed then qualifying litigants would be entitled to receive legal aid from the commencement of proceedings just as they were previously.
} 


\section{(c) Greater judicial case management and use of interlocutory procedures}

The current mechanism to apply to strike out or excise inadmissible evidence is not often taken up by counsel, ${ }^{371}$ and the court will frequently elect to defer any challenge to admissibility until the conclusion of the hearing. By then the damage will usually have been done. For the court to reject evidence, it must expressly place no weight upon it. ${ }^{372}$

Interlocutory challenges to evidence could be dealt with more efficiently on the papers by filing an objection and the judge issuing a written decision. While such a procedural step may appear retrograde in terms of requiring more front-end judicial resourcing (at a time when the government is looking at reducing court costs), it is likely that judicial time expended at this early point would result in shorter hearings, less acrimony and better prospects of early settlement resulting in greater efficiency overall: ${ }^{373}$

Wholesale admission of hearsay can tend to increase the expense of proceedings by multiplying witnesses. This is a trend which should be resisted in the attempt to make Family Court proceedings as simple and inexpensive as is consistent with justice and welfare.

Linked with these issues is the requirement to monitor compliance with the Evidence Act until compliance becomes habitual. At present, Family Court judges act as gatekeepers of all the evidence and as case managers for proceedings. It would be a straightforward procedural change for Judges to compulsorily consider evidential issues at an early review of the papers filed, or at the first court call of the matter when issues are clearly identified. ${ }^{374}$ One disadvantage of waiting until a court review is that the matter will not be listed before a Judge until the defence period has expired, by which time the respondent will have already had to file a defence and affidavit in reply responding to the objectionable evidence. A further disadvantage is that, unless the case is earmarked as complex, various judges may deal with the case at different court events and will be less likely to exclude evidence unless they know they will be the hearing judge.

371 As noted by Stephen van Bohemen in "Evidence: When it's an Issue in the Family Court" (2010) 6 NZFLJ 271 at 271: "Family Law practitioners are frequently confronted by irrelevant and/or argumentative evidence. However, the absence of many decisions on the issue indicates that few practitioners apply to have such evidence struck out."

$372 \quad$ Nicholls $v$ Nicholls, above n 98, at 317.

373 Ibid, 317).

$374 \quad$ Usually a Directions Conference, Issues Conference or Judicial Conference in a relationship property matter. 


\section{One Court-One Judge}

Current research is underway to look at the One Court, One Judge ${ }^{375}$ system for family law cases and criminal cases. The proposal is to create integrated domestic violence courts which deal with all criminal and family proceedings where family violence is the common thread. While there would continue to be both the criminal and civil standards of proof applying to the specific proceedings which would still be heard separately, the evidence brought for each set of proceedings could be shared. Although the family proceedings evidence could not be used to decide guilt in the criminal proceedings, it would still be used for such things as bail applications and sentencing. ${ }^{376}$

If such courts are to be implemented, there is even more reason to ensure that one invariable set of rules governs the admissibility of evidence, despite the different standards of proof which apply in each jurisdiction. There is a risk of unconscious bias if improper evidence is tendered in family proceedings and then considered by the same judge determining the criminal matters. The need for correctness about what evidence comes before the court is heightened when criminal charges are at stake.

\section{Summary}

In summary, repeal of the rule outright appears to be the most obvious solution to remedy the disadvantages the rule creates. However, the law still needs to protect vulnerable citizens by ensuring that appropriate evidence is not excluded from court proceedings. Repeal of the rule with a consequent amendment in the Evidence Act 2006 about non-availability or noncompellability of children under 18 in civil or family proceedings would better achieve an outcome which balances the competing needs of justice and vulnerable participants. The additional Family Court procedural measures proposed would be complementary adjuncts to any reforms implemented, and would result in fairer and timelier court proceedings. Violence (NZ Law Foundation/Victoria University of Wellington, Wellington, 2017).

376 At [67]-[70].
} 
New Zealand originally adopted the "any evidence" rule in the package of Imperial Statutes imported as law during the nineteenth century. The rule had its origins in the doctrine of parens patriae designed to protect vulnerable participants in the legal system. The rule is now of general application and able to be used to the advantage of either party in all family proceedings. This long-standing history of the rule in the Family Court context has allowed a practice to develop where inadmissible evidence is routinely offered and admitted.

The "any evidence" rule undoubtedly dispenses with formality, but it is questionable whether the rule enables proceedings to be dealt with as speedily, inexpensively and simply as possible, as required by the three key legislative provisions. ${ }^{377}$ The very shortcuts employed by the "any evidence" rule are not consistent with justice and are at the cost of the parties and more importantly the child at the centre of the inquiry. On these grounds, sound policy justifies revocation of the rule due to the detriment it can inadvertently create.

Years of research into evidence law in New Zealand finally culminated in the passing of the Evidence Act 2006 which is intended as a code of general application. The "any evidence" rule remains an anomaly in this landscape. The amendment to the rule in 2013 effectively confirmed the Evidence Act 2006 as the primary gateway for the admission of evidence, but kept the rule in case the Evidence Act was deficient. In the re-writing of the rule, there was only a cursory analysis of its necessity and utility. Retaining the rule in its current form 'just in case' is an insufficient and unprincipled rationale for its retention.

The Evidence Act 2006 now bridges the gap in admitting important evidence that may have been previously excluded. My analysis of selected cases identified very few cases where the rule is required, and these involve children's cases. The wide definition of relevance, the improved ambit to admit reliable hearsay, business records, propensity and non-expert opinion $^{378}$ together ensure that important evidence will not be excluded.

In a country which is striving towards a more principled, predictable and transparent evidential framework, the "any evidence" rule continues to operate against those basic tenets. Although it remains in the rule book for other courts such as the Coroners Court, Environment Court and Maori Land Court, the rule does not appear to have created the reputation of lawlessness in those jurisdictions that is sometimes levelled against the Family Court.

\footnotetext{
377 The Family Court Rules 2002, r 3; the Domestic Violence Act 1995, s 5; the Property (Relationships) Act 1976, s 1N(d). The Evidence Act 2006 has a similar goal of "avoiding unjustifiable expense and delay."

$378 \quad$ Evidence Act 2006, s 24: “...where this is necessary for the witness to communicate, or the fact-finder to understand, what the witness saw, heard, or otherwise perceived."
} 
There is no doubt that the "any evidence" rule continues to encourage the introduction of evidence that falls short of accepted evidential standards. Repealing or severely restricting the rule would have a positive effect on the quality of evidence and the reputation of the Family Court. Adding procedural steps to ensure that evidence is remedied within a specific timeframe if the matter is defended should ameliorate any unfairness caused by the inclusion of hearsay in a without notice application.

As the "any evidence" rule is a matter of judicial discretion, it is natural that decisions about admissibility are coloured by a judge's personal view, with the risk of injustice resulting in some cases. ${ }^{379}$ One commentator on the theory of increasing judicial discretion to determine admissibility of evidence noted: ${ }^{380}$

The push toward judicial discretion and "universal admissibility" (also called "free proof") has costs of which reformers were unaware. Moving toward a universal admissibility standard and increasing judicial discretion sacrifices the promise that legal conclusions will be reached on a uniform standard of knowledge reproducible across cases. This in turn jeopardizes the promise of justice, especially in criminal trials...

While we are here considering the civil jurisdiction of the Family Court, there is no other area of law which can so intimately impact on ordinary citizens. The view of some lawyers and politicians that the Family Court is an ill-disciplined quasi-legal forum is unjustified, but further damaged by the current approach to evidence. New Zealand's wide sweeping promise in the Evidence Act is for facts to be established by logical rules, for rights protected under the New Zealand Bill of Rights Act 1990 to be affirmed, for fairness to parties and witnesses to be promoted, for rights of confidentiality and other important public interests to be protected, for unjustifiable expense and delay to be avoided and for access to the law of evidence enhanced across all courts. These aspirational promises and gains are eroded and devalued by the permissive and unchecked discretion left in place for family proceedings by the "any evidence" rule.

\footnotetext{
379 Although it has been argued by Richard Chisholm in "Perceptions and Values: their Role in Family Law Decisions" (2003) 16(4) Australian Family Lawyer 1, that judicial discretion is overstated due to specific constraints imposed by the legal framework including: the judge has to apply the law; the decision is based on evidence; the decision is based on argument and submissions by the parties; the judge gives a judgment that indicates the reasons for decision (with some qualifications); the decision is subject to appeal and that the court is open to the public.

380 Kenneth M Ehrenberg "Less Evidence, More Knowledge” (2015) 60(2) McGill LJ 173 at 176.
} 
Bibliography

PRIMARY SOURCES

\section{A Cases}

Arrington v Slater [2016] NZFC 5176

$B v F$ (1992) 8 FRNZ 714

Banda v Hart (1998) 17 FRNZ 667, [1998] NZFLR 930

Barlow v Barlow 16/9/98, Judge Inglis QC, FC Christchurch FP009/473/96

Black v R [2012] NZCA 482

BPF v LTD [Admissibility of evidence] [2010] NZFLR 253

BSH v Ministry of Social Development HC Wellington CIV-2009-485-000403, 13 August 2009

Brock v Norton [2016] NZFC 468

Coleman v Coleman 6/8/97, Judge Doogue, DC Auckland FP515/91

$D v N$ [2017] NZHC 1211

$D v O$ [2006] NZFLR 137, (2005) 24 FRNZ 894

De Boock v Hoover [2015] NZFC 5848

Donovan v Graham (1991) 4 PRNZ 311

Department of Social Welfare v T (1988) 4 FRNZ 477

Estate of Pinker v Pinker [2015] NZHC 660; (2015) 30 FRNZ 174

Faw v Faw [2015] NZFC 2215

FSE v SJH FC Christchurch FAM-1000-009-001560/1561, 2 September 2011

$G v L$ [2016] NZCA 571; [2017] NZFLR 31 (also cited as McQueen v Penn)

Gebrein v Todd [2015] NZFC 4949

Gibb v Watt [2015] NZFC 5715

Gillick $v$ West Norfolk Area Health Authority [1986] 1 AC 112 (UKHL).

Goodwin v Rensford [2015] NZFC 2156; [2015] NZFLR 794H v G (1999) 18 FRNZ 572

JLE v JAR-B [Protection order [2013] NZFLR

$K v G$ [2009] NZFLR 253

Kacem v Bashir [2010] NZSC 112, [2011] 2 NZLR 1, [2010] NZFLR 884, (2010) 28 FRNZ 483

Kepa v Hautapu (1998) 17 FRNZ 100

KRM v BRM [2012] NZFC 5325

$L v R$ [2017] NZHC 590, [2017] NZFLR 177

Lowe v Auckland Family Court and Way [2017] NZHC 758

$M v B$ [2006] 3 NZLR 660

Magan v Magan [2014] NZFC 8181

McLay v Ministry of Social Development [2014] NZHC 3398

Marsden v Bernard [2016] NZFC 4730 
ME $v$ VEPN FC Napier FAM-2008-041-000481, 1 September 2011

$N J G v S S$ [2013] NZHC 914

Nicholls $v$ Nicholls [1996] NZFLR 311

$O v S$ FC Lower Hutt FAM-2008-032-132, 7 April 2008

Pallin v Dept of Social Welfare [1983] NZLR 266, (1983) 2 NZFLR 321, (1983) 1 FRNZ 117.

Also known as $P v$ Dept of Social Welfare

PCH v AMK Dunedin FAM-2006-005-000004, 27 May 2011

Pita v Putahi (2000) 19 FRNZ 98

$R v$ Bain [1996] 1 NZLR 129; (1995) 13 CRNZ 684 (CA)

$R v$ Gwaze [2010] NZSC 52, [2010] 3 NZLR $734 R v$ Smith [2007] NZCA 400

$R v$ Smith [2007] NZCA 400

Radisich v Taylor HC Auckland CIV-2007-404-003276, 23 March 2009

Re Rudd (1994) 12 FRNZ 387

Re W (Minors) (Wardship: Evidence) [1990] 1 FLR 203

Starr v O'Meehan [2016] NZFLR 409

Surrey v Surrey [2010] 2 NZLR 581; [2010] NZFLR 1.

Taylor-Edwards v Palmer [2002] NZFLR 812, (2002) 21 FRNZ 588

TJD v TLB FC Napier FAM-2005-041-591, 13 July 2007

$T v G$ [2007] NZFLR 121

$T$ v $M$ (1984) 1 FRNZ 326

Thornton $v R$ [2017] NZCA 256

$W$ (Children) [2010] UKSC 12

Walker $v$ Walker [2006] NZFLR 768

Wells v Family Court HC Wellington, CP no. 245/94, 7 December 1994

Wi $v R$ [2010] 2 NZLR 11

Zv Dental Complaints Assessment Committee [2008] NZSC 55, [2009] 1 NZLR 1

\section{$B$ Legislation and Bills}

1 New Zealand

Care of Children Act 2004

Child Support Act 1991

Children, Young Persons, and Their Families Act 1989

Coroners Act 2006

Criminal Procedure (Transfer of Information) Regulations 2013

Destitute Persons Act 1908

Domestic Violence Act 1995

Evidence Act 2006

Family Courts Act 1980

Family Courts Amendment Act 2013 
Family Court Rules 2002

Family Proceedings Act 1980

Family Protection Act 1955

Guardianship Act 1968

Intellectual Disability (Compulsory Care and Rehabilitation) Act 2003

Lawyers and Conveyancers Act (Lawyers: Conduct and Client Care) Rules 2008

Mental Health (Compulsory Assessment and Treatment) Act 1992

Property (Relationships) Act 1976

Protection of Personal and Property Rights Act 1988

Resource Management Act 1991

Te Ture Whenua Maori Act 1993

\section{United Kingdom}

Children Act 1989

Children (Admissibility of Hearsay Evidence) Order 1993 (no 621) (UK)

3 Australia

Family Law Act 1975

\section{International Conventions}

United Nations Convention on the Rights of the Child (UNCROC)

\section{SECONDARY SOURCES}

\section{Parliamentary materials}

1 Submissions to Select Committees

Submission of the New Zealand Law Society on the Family Court Proceedings Reform Bill 2012 (13 February 2013).

Submission of the Family Court Judges on the Family Court Proceedings Reform Bill 2012

\section{Governmental materials}

1 Government and Ministerial Reports

David Beattie Royal Commission on the Courts (NZ Government, Wellington, 1978) ("the Beattie report") 
Ministry of Justice Family Court Proceedings Reform Bill: Departmental Report (April 2013)

Ministry of Justice Improving the quality of initial processes and evidence (Obtained under Official Information Act 1982 Request to the Ministry of Justice February 2016).

Ministry of Justice Reviewing the Family Court: a public consultation paper ( 20 September 2011)

Various documents from the Ministry of Justice (Obtained under Official Information Act 1982 Request to the Ministry of Justice February 2016). Information received on 12 February 2016.

\section{Other Reports}

Rae Kaspiew and others Evaluation of the 2006 family law reforms (Australian Institute of Family Studies, Melbourne, December 2009)

Zoë Lawton One Court, One judge: An Integrated Court System for New Zealand Families Affected by Violence (NZ Law Foundation/Victoria University of Wellington, Wellington, 2017)

\section{E Texts and theses}

B D Inglis QC New Zealand Family Law in the $21^{\text {st }}$ Century (Brookers, Wellington, 2007)

John Eekelaar Family Law and Personal Life (OUP, Oxford, 2006)

Elisabeth McDonald Principles of Evidence in Criminal Cases (Brookers, Wellington, 2012)

Mavis Maclean, John Eekelaar and Benoit Bastard (Eds) Delivering Family Justice in the 21st Century (Hart Publishing Ltd, Oxford, United Kingdom, 2015)

Richard Mahoney and others The Evidence Act 2006: Act and Analysis ( $3^{\text {rd }}$ ed, Brookers, Wellington, 2014)

John Spencer and Rhona Flin The Evidence of Children: The Law and Psychology (Blackstone Press Ltd, Great Britain, 1990)

Evan Stark Interpersonal Violence: Coercive Control: The Entrapment of Women in Personal Life (Cary, US: Oxford University Press, Incorporated, 2007. ProQuest elibrary)

Alex Stein Foundations of Evidence Law (Oxford, OUP, 2005)

Nicola Taylor "Care of Children: Families, Dispute Resolution and the Family Court" $(\mathrm{PhD}$ Thesis, University of Otago, December 2005) 


\section{F Journal Articles}

Victoria Blakeley and others "Social Media Evidence in Family Law: What is Probative Value of Different Types and What Kinds of Social Media Evidence Can be Used in Regards to Which Specific Rules of Evidence" (2015) 5(2) Family Law Review 81-101 (<ssrn .com/abstract $=2664926>$ )

Stephen van Bohemen "Evidence: When it's an issue in the Family Court" (LexisNexis Child and Youth Law Conference, Auckland, 2009)

Stephen van Bohemen and Jill Moss "Domestic Violence Act proceedings - New Rigour in Evidence and Proof" (paper presented to the Family Law Conference, Positive Vibes, Dunedin, October 2015) at 401.

Sean Brennan "Self-litigants in the Family Court: How They Are Compromising Access to Justice" (2015) 8 NZFLJ 150

Richard Chisholm in "Perceptions and Values: their Role in Family Law Decisions" (2003) 16(4) Australian Family Lawyer 1

Helen Cull "Rules of Evidence in the Family Court" (NZLS Conference Seminar Paper, Wellington, 2009) at 155

C Murray Earl "Can George (aged 12) tell the court his story? - Children's evidence in the Family Court” (2017) 18(2) Family Advocate 12

Kenneth M Ehrenberg “Less Evidence, More Knowledge” (2015) 60(2) McGill LJ 173

Patrick Fitzgerald and Michelle Fernando "Has the Less Adversarial Trial Process Abolished the Rules of Evidence” (2009) 20 (3) Australian Family Lawyer 25

H Ho "Legal professional privilege and the integrity of legal representation" (2006) 9(2) Legal Ethics 163

Simon Jefferson QC “A Review of the Family Court 2011: Sorry, Snow White Can't Afford Dwarves This Year" (paper presented to Parliament in 2011 at the Symposium on Family Law, Wellington, 2011)

Bernard Robertson "Bain, Bayes and basics: Relevance under the Evidence Act 2006” (2010) 24 New Zealand Universities Law Review 167

\section{G Looseleaf Texts and online materials}

LexisNexis Family Law Service (online ed, LexisNexis)

Resource Management Act and Commentary (online ed, Westlaw NZ) 